\title{
Title: Expansion of Functional Regulatory T Cells Using Soluble RAGE Prevents Type 1 Diabetes
}

Authors: Sherman S. Leung ${ }^{1,2}$, Danielle J. Borg ${ }^{1,3}$, Domenica A. McCarthy ${ }^{1}$, Tamar E. Boursalian $^{4}$, Justen Cracraft ${ }^{4}$, Aowen Zhuang ${ }^{1}$, Amelia K. Fotheringham ${ }^{1,2}$, Nicole Flemming ${ }^{1,2}$, Thomas Watkins ${ }^{5}$, John J. Miles ${ }^{5}$, Per-Henrik Groop ${ }^{6-9}$, Jean L. Scheijen ${ }^{10,11}$, Casper G. 6 Schalkwijk $^{10,11}$, Raymond J. Steptoe ${ }^{12}$, Kristen J. Radford ${ }^{2,13}$, Mikael Knip ${ }^{6,7,14}$, Josephine M. 7 Forbes $^{1,9,15^{*}}$

\section{Affiliations:}

${ }^{1}$ Glycation and Diabetes, Mater Research Institute - The University of Queensland (MRI-UQ), Translational Research Institute (TRI), Brisbane, QLD 4102, Australia.

${ }^{2}$ School of Biomedical Sciences, The University of Queensland, Brisbane, QLD 4067, Australia. ${ }^{3}$ Inflammatory Disease Biology and Therapeutics, MRI-UQ, TRI, Brisbane, QLD 4102, Australia.

${ }^{4}$ Type 1 Diabetes Research Center, Novo Nordisk, Seattle, WA 98109, US.

${ }^{5}$ Centre for Biodiscovery and Molecular Development of Therapeutics, Australian Institute of Tropical Health and Medicine (AITHM), James Cook University, Cairns, QLD 4870, Australia.

${ }^{6}$ Research Programs Unit, Diabetes and Obesity, University of Helsinki, 00100 Helsinki, Finland.

${ }^{7}$ Folkhälsan Research Center, 00290 Helsinki, Finland.

${ }^{8}$ Abdominal Center Nephrology, University of Helsinki and Helsinki University Hospital, 00100 Helsinki, Finland.

${ }^{9}$ Baker IDI Heart and Diabetes Institute, Melbourne, VIC 3004, Australia.

${ }^{10}$ Department of Internal Medicine, Laboratory for Metabolism and Vascular Medicine, Maastricht University, 6211 LK Maastricht, The Netherlands.

${ }^{11}$ Cardiovascular Research Institute Maastricht, 6229 ER Maastricht, The Netherlands.

${ }^{12}$ The University of Queensland Diamantina Institute, TRI, Brisbane, QLD 4102, Australia.

${ }^{13}$ Cancer Immunotherapies, MRI-UQ, TRI, Brisbane, QLD 4102, Australia.

${ }^{14}$ Children's Hospital, University of Helsinki and Helsinki University Hospital, 00100 Helsinki, Finland.

${ }^{15}$ Mater Clinical School, The University of Queensland, Brisbane, QLD 4101, Australia.

*Corresponding Author: josephine.forbes@mater.uq.edu.au 
Abstract

Type 1 diabetes (T1D) is an autoimmune disease with no cure. Therapeutic translation has been hampered by preclinical reproducibility. Here, short-term administration of an antagonist to the receptor for advanced glycation end products (sRAGE) protected against murine diabetes at two independent centers. Treatment with sRAGE increased regulatory $\mathrm{T}$ cells $\left(\mathrm{T}_{\text {regs }}\right)$ within islets, pancreatic lymph nodes and spleen, increasing islet insulin expression and function. Diabetes protection was abrogated by $\mathrm{T}_{\text {reg }}$ depletion and shown to be dependent on antagonizing RAGE

41 using knockout mice. Human $\mathrm{T}_{\text {regs }}$ treated with a RAGE ligand downregulated genes for suppression, migration and $\mathrm{T}_{\text {reg }}$ homeostasis $(F O X P 3, I L 7 R, T I G I T, J A K 1$, STAT3, STAT5b, CCR4). Loss of suppressive function was reversed by sRAGE, where $\mathrm{T}_{\text {regs }}$ increased proliferation and suppressed conventional $\mathrm{T}$ cell division, confirming that sRAGE expands functional human

$45 \mathrm{~T}_{\text {regs. }}$ These results highlight $\mathrm{sRAGE}$ as an attractive treatment to prevent diabetes, showing 46 efficacy at multiple research centers and in human $\mathrm{T}$ cells. 


\section{Introduction}

Type 1 diabetes (T1D) is an autoimmune disease involving a heterogeneous interplay between genetics and environmental factors resulting in $\mathrm{T}$ cell mediated destruction of insulin-producing $\beta$ cells (Atkinson et al., 2014). T1D incidence is increasing at 2-3\% per year worldwide, elevating the risk for premature death and costing $\$ 14$ billion per annum in healthcare in the USA alone (Tao et al., 2010). Risk factors for developing T1D include decreases in functional regulatory $\mathrm{T}$ cells $\left(\mathrm{T}_{\text {regs }}\right)$ (Brusko et al., 2005) and increased numbers of autoantigen-specific conventional $\mathrm{T}$ cells $\left(\mathrm{T}_{\text {convs }}\right)$, particularly those with an effector phenotype $\left(\mathrm{T}_{\text {eff }}\right)$ (Laban et al., 2018). Early phase clinical trials promoting the expansion of $T_{\text {regs }}$, thereby suppressing $T_{\text {conv }}$ activation, have shown promise in preserving insulin production after the diagnosis of T1D (Alhadj Ali et al., 2017; Rosenzwajg et al., 2015), but await validation in larger cohorts. However, it is now recognized that interventions aimed at reversing clinically diagnosed T1D may be "too late", with Phase III clinical trials not reaching primary end points (Insel et al., 2015). As a result, promising therapeutics targeting $\mathrm{T}$ cells are being repurposed for use prediabetes to prevent the onset of T1D (NCT01030861; NCT01773707). Recently, the former study, which was a phase II randomized trial, reported that Teplizumab - a Fc-receptor nonbinding anti-CD3 monoclonal antibody - significantly delayed the onset of T1D (Herold et al., 2019).

In fact, a framework for staging prediabetes was recently established which involves standardized screening to accurately stratify individuals into Prediabetes Stages 1-3 so that novel therapies can be tested within a suitable therapeutic window (Insel et al., 2015). Thus, interventions delivered prediabetes are clinically feasible, have a greater chance of preserving insulin secretion and could prevent the onset of T1D. 
The receptor for advanced glycation end products (RAGE) is a pattern recognition receptor implicated in inflammatory disease and is expressed in various cells involved in T1D including T cells (reviewed in (Leung et al., 2016)). Recently, changes in RAGE expression have been associated with the risk for developing T1D in humans (Salonen et al., 2015; Salonen et al., 2014; Salonen et al., 2016). Furthermore, T cells from at-risk individuals who progress to T1D, have greater RAGE expression, which enhances $\mathrm{T}$ cell cytokine production and survival (Durning et al., 2016). Natural history studies have further revealed that polymorphisms in the RAGE gene (AGER) decrease circulating soluble RAGE (sRAGE) concentrations (Salonen et al., 2014), which is a naturally occurring antagonist that competes for RAGE ligands, increasing the risk of T1D (Forbes et al., 2011). The decreases in circulating sRAGE also coincide with seroconversion to autoantibodies against islet auto-antigens in at-risk individuals (Salonen et al., 2015; Salonen et al., 2016). Therefore, this deficiency in circulating sRAGE is a novel therapeutic target for preventing the onset of T1D.

Here, we targeted the deficiency in circulating sRAGE levels prediabetes by short-term administration of recombinant human sRAGE with the aim of preventing diabetes onset in mice. We show that it acts in an immunomodulatory manner to decrease diabetes incidence at two independent research centers through $\mathrm{T}_{\text {reg }}$ modulation. Additionally, sRAGE increased the proportion of $\mathrm{T}_{\text {regs }}$ in the islet infiltrating leukocytes, pancreatic lymph nodes (PLN) and spleen, which reduced islet infiltration and preserved islet numbers, insulin expression and $\beta$ cell function. Ex vivo, sRAGE promoted the expansion of human $\mathrm{T}_{\text {regs }}$ and reduced $\mathrm{T}_{\text {conv }}$ proliferation in co-culture, whereas $T_{\text {regs }}$ cultured in the presence of the RAGE ligand, AGEs, had reduced suppressive function. Our data suggest that short-term delivery of sRAGE prediabetes is an 
bioRxiv preprint doi: https://doi.org/10.1101/2020.01.10.902627; this version posted January 11, 2020. The copyright holder for this preprint (which was not certified by peer review) is the author/funder, who has granted bioRxiv a license to display the preprint in perpetuity. It is made available under aCC-BY-ND 4.0 International license.

92 effective modulator of functional $\mathrm{T}_{\text {reg }}$ expansion and has efficacy to prevent diabetes and

93 possibly other autoimmune diseases. 
Mater Medical Research Institute Limited - Confidential

\section{Results}

\section{Short-Term sRAGE Treatment Provides Lasting Protection from Diabetes in Multi-Site}

\section{Trial}

There is no cure for T1D so there is a desperate need for reproducible and translatable novel disease targets. Here, we administered recombinant human sRAGE prediabetes to correct the deficiency in circulating sRAGE seen in at-risk progressors who develop T1D (Salonen et al., 2015; Salonen et al., 2014; Salonen et al., 2016), using a preclinical study design tested for reproducibility at two independent research centers (Figure 1A).

When sRAGE was administered intraperitoneally twice daily, the incidence of diabetes decreased 3-fold when compared with vehicle treated mice (Figure 1B, Site 1). We found comparable results at an independent research center with greater diabetes penetrance (Figure 1B, Site 2), where sRAGE treatment resulted in a 2.8-fold reduction in diabetes incidence (vs. untreated; Figure 1B). At a greater dose administered only once daily, sRAGE treatment was even more effective and decreased diabetes incidence by 4-fold (vs. untreated; Figure 1B).

Non-fasted blood glucose levels in sRAGE treated mice were significantly lower over the study duration when compared with vehicle and untreated mice using regression analysis (Figure 1C). Furthermore, the regression line and its confidence intervals for the once daily sRAGE treatment regimen were lower than those of the remaining groups, until approximately day 200 when both sRAGE groups had overlap (Figure 1C). Blood glucose variability was also reduced following sRAGE administration, as determined by decreased residuals from the regression line (vs. vehicle/untreated; Figure 1C). These findings demonstrate that short-term sRAGE treatment significantly reduces diabetes incidence and improves long-term blood glucose control. From 
Mater Medical Research Institute Limited - Confidential

116 herein, we characterize the effects of sRAGE given twice daily because we were able to observe

117 significant protection from diabetes at this lower dose.

sRAGE Therapy Decreases Islet Infiltration and Increases Islet Numbers

Immune cell infiltration into the pancreatic islets and islet destruction are pathological hallmarks of T1D (Atkinson et al., 2014), so we hypothesized that these facets of disease pathogenesis would be improved by sRAGE treatment. To this end, immediately after therapy completion on day 64 , mice treated with sRAGE had a considerably reduced islet infiltration index as compared with vehicle (Figure 1D). This was due to a decrease in the numbers of islets presenting with high grade insulitis ( $>75 \%$ infiltrate, grade 4$)$ and an increase in islets without insulitis $(0 \%$ infiltrate, grade 0 ; Figure $1 \mathrm{E}$ and $1 \mathrm{~F})$. Interestingly, by day 80 , the islet infiltration index did not differ between groups (Figure 1D) but unexpectedly, sRAGE treated mice had a small increase in the proportion of islets with grade 4 insulitis $(>75 \%$ infiltration; Figure 1E and $1 F)$. When sRAGE treated mice were examined on day 225 , we found a significant reduction in the islet infiltration index (Figure 1D), an increased proportion of islets without immune cell infiltration and a reduced proportion of islets that scored 4 (vs. vehicle; Figure 1E and 1F). Islet numbers decreased over the study duration in both cohorts (Figure 1G), but sRAGE treatment preserved a greater number of islets by day 225 (Figure $1 \mathrm{G}$ ). Islet numbers did not differ between groups at the other time points (Figure 1G).

\section{sRAGE Rapidly Increases $\mathbf{T}_{\text {reg }} / \mathbf{T}_{\text {eff }}$ Ratios in the PLN and Spleen}

$\mathrm{T}_{\text {regs }}$ in the PLN and spleen regulate islet infiltration, influencing the development of diabetes (McNally et al., 2011). Thus, we tested whether sRAGE could influence the numbers of $\mathrm{T}_{\text {regs }}$ and $\mathrm{T}_{\text {convs }}$ in these lymphoid tissues, in addition to $\mathrm{T}_{\text {reg }} / \mathrm{T}_{\text {eff }}$ ratios (gating strategies in Figure $\mathrm{S} 1$ ). Immediately after sRAGE therapy on day 64 , higher numbers of $\mathrm{CD} 4^{+} \mathrm{CD} 8{ }^{-} \mathrm{CD} 25^{+} \mathrm{Foxp} 3^{+} \mathrm{T}_{\text {regs, }}$, 
Mater Medical Research Institute Limited - Confidential

139

140

141

142

143

144

145

146

147

148

149

150

151

152

153

154

155

156

157

158

159

160

161

as well as FoxP3- ${ }^{-} \mathrm{CD} 4^{+}$and $\mathrm{FoxP}^{-} \mathrm{CD}^{+} \mathrm{T}_{\text {convs }}$ were observed in the PLN and spleen (vs. vehicle; Figure S2A-S2C). This is consistent with previous reports showing that sRAGE treatment is immunomodulatory, since it can increase the numbers of monocytes, macrophages and B cells (Pullerits et al., 2006). However, there are no studies showing that sRAGE can expand the numbers of $\mathrm{T}$ cells, nor its specific effects on the $\mathrm{T}$ cell subsets of $\mathrm{T}_{\text {regs, }} \mathrm{T}_{\text {convs }}$ and Teffs.

Here, we found a superior increase in PLN $\mathrm{T}_{\text {reg }}$ numbers, resulting in elevated $\mathrm{T}_{\text {reg }} / \mathrm{T}_{\text {eff }}$ cell ratios in sRAGE treated mice (Figure $2 \mathrm{~A}-2 \mathrm{C}$ ), which suggested the local environment was more regulated. Despite the increase in splenic $\mathrm{T}_{\text {regs }}$, its ratio to $\mathrm{T}_{\text {eff }}$ cells remained unchanged on day 64 (Figure 2A-2C). There was no change in the activation status of FoxP3-CD4 ${ }^{+}$and FoxP3$\mathrm{CD}^{+} \mathrm{T}_{\text {convs }}$ following sRAGE treatment in either lymphoid compartments, as determined by the expression of the CD62L and CD44 adhesion molecules (Figure S2B and S2C).

By day 225, sRAGE treated mice had decreased numbers of CD4 ${ }^{+} \mathrm{CD} 8{ }^{-} \mathrm{CD} 25^{+} \mathrm{Foxp}^{+} \mathrm{T}_{\text {regs }}$ and FoxP3-CD8 ${ }^{+} \mathrm{T}_{\text {convs }}$ in the PLN, as well as reduced numbers of FoxP3-CD4 ${ }^{+}$and $\mathrm{FoxP}^{-} \mathrm{CD}^{+}$ $\mathrm{T}_{\text {convs }}$ in the spleen, as compared with vehicle (Figure S3A-S3C). This suggested that short-term sRAGE intervention persistently dampened the immune response over the study duration. In support of this, sRAGE provided a long-lasting increase in the $\mathrm{T}_{\text {reg }} / \mathrm{T}_{\text {eff }}$ cell ratios in the spleen (vs. vehicle; Figure 2D-2F). Furthermore, the localized increase in $\mathrm{T}_{\text {reg }} / \mathrm{T}_{\text {eff }}$ cell ratios seen in the PLN of sRAGE treated mice on day 64, was resolved by day 225 (Figure 2D-2F). The proportions of CD62 $\mathrm{L}^{+} \mathrm{CD} 44^{-}$naïve, CD62 $\mathrm{L}^{-} \mathrm{CD} 44^{+}$effector and $\mathrm{CD} 62 \mathrm{~L}^{+} \mathrm{CD} 44^{+}$memory subsets in the $\mathrm{T}_{\text {conv }}$ populations remained unchanged between groups on day 225 (Figure $\mathrm{S} 3 \mathrm{~B}$ and $\mathrm{S} 3 \mathrm{C}$ ).

To determine if changes in antigen presenting cells (APCs) could influence tolerance, we also quantified the numbers of $\mathrm{CD}^{+}$and $\mathrm{CD} 11 \mathrm{~b}^{+}$conventional dendritic cells (cDCs), plasmacytoid 
Mater Medical Research Institute Limited - Confidential

162 dendritic cells (pDCs) and macrophages on day 64. This is important because $\mathrm{CD}^{+} \mathrm{cDC}$

163 interactions with autoreactive $\mathrm{CD}^{+} \mathrm{T}$ cells contribute towards tolerance in NOD mice (Price et

164 al., 2014) and, within the lymph nodes, $\mathrm{CD}^{+}$cDCs can directly induce $\mathrm{T}_{\text {regs }}$ via TGF- $\beta$

165 (Yamazaki et al., 2008). CD11 $\mathrm{b}^{+} \mathrm{cDCs}$ and $\mathrm{pDCs}$ are also potent inducers of $\mathrm{T}_{\text {regs }}$ (Lippens et al.,

166 2016; Tordesillas et al., 2018). Here, we found an increase in all dendritic cell subsets within the

167 spleen but no significant changes within the PLN (Figure S4A). This supports the hypothesis that

168 after sRAGE treatment, dendritic cells do not significantly contribute to increased proliferation

169 or differentiation of $\mathrm{T}_{\text {regs }}$ within a major lymphoid tissue in T1D. Interestingly, we found

170 increased numbers of macrophages in both the PLN and spleen (Figure S4B), consistent with

171 previous studies using sRAGE (Pullerits et al., 2006).

172 Overall, these data show that sRAGE preferentially increases the numbers of $\mathrm{T}_{\text {regs }}$ rather than

$173 \mathrm{~T}_{\text {eff }}$ cells in the PLN in the short-term. In the long-term, sRAGE reduces both $\mathrm{T}_{\text {reg }}$ and $\mathrm{T}_{\text {eff }}$ cell

174 numbers in the PLN and spleen, maintaining higher splenic $\mathrm{T}_{\text {reg }} / \mathrm{T}_{\text {eff }}$ ratios in mice at risk of 175 diabetes.

\section{Diabetes Prevention by sRAGE is Dependent on T $_{\text {regs }}$ and RAGE Expression}

177 To further delineate the effects of sRAGE on $\mathrm{T}_{\text {regs, }}$ an accelerated model of autoimmune diabetes was used that tests the immunological aspects of disease while excluding other elements such as islet dysfunction. Here, we performed the adoptive transfer of diabetes by injecting splenocytes from recently diabetic NOD/ShiLt mice into NOD/SCID recipients, that were then

181 administered (i) vehicle and isotype control IgG, (ii) vehicle and anti-folate receptor 4 (FR4) 182 antibodies to deplete $\mathrm{T}_{\text {regs, }}$ (iii) sRAGE and isotype control IgG, or (iv) sRAGE and anti-FR4 183 antibodies to deplete $\mathrm{T}_{\text {regs }}$ (Figure $2 \mathrm{G}$ ). We found that $72 \%$ and $78 \%$ of NOD/SCID recipient 
Mater Medical Research Institute Limited - Confidential

185

186

antibodies, respectively (Figure $2 \mathrm{H}$ ). None of the NOD/SCID mice treated with sRAGE and isotype control IgG developed diabetes, whereas $56 \%$ of those that received sRAGE and antiFR4 antibodies to deplete $\mathrm{T}_{\text {regs }}$ developed diabetes (Figure $2 \mathrm{H}$ ). We also found marked reductions in $\mathrm{CD}^{+} \mathrm{CD}^{-} \mathrm{CD} 25^{+} \mathrm{FoxP} 3^{+} \mathrm{T}_{\text {reg }}$ proportions for mice treated with anti-FR4 antibodies whereas sRAGE and isotype control IgG treated mice had an increased proportion of $\mathrm{T}_{\text {regs }}$ (Figure 2I). These data provide direct support that $\mathrm{T}_{\text {regs }}$ are required for $\mathrm{sRAGE}$ to protect against diabetes.

sRAGE competes for RAGE ligands that are also recognized by other receptors including TLRs (Das et al., 2016). Thus, we investigated if the capacity for sRAGE to preferentially increase $\mathrm{T}_{\text {regs }}$ was dependent on RAGE expression. First, we established that cell surface RAGE was present on $\mathrm{CD}^{+} \mathrm{CD}^{-} \mathrm{CD} 25^{+} \mathrm{Foxp}^{+} \mathrm{T}_{\text {regs }}$ in the PLN and spleen in NOD/ShiLt mice on day 50 of life (Figure 3A and 3B), which is when we commenced sRAGE treatment in our multi-site preclinical trial. Then, in the widely used C57BL/6 strain, we administered sRAGE to wild-type or RAGE knockout (RAGE KO) mice on days 50 to 64 of life (Figure 3C).

Consistent with our findings in NOD/ShiLt mice, there was a significant increase in the $\mathrm{T}_{\text {reg }} / \mathrm{T}_{\text {eff }}$ cell ratios in both the PLN and spleen of wild-type C57BL/6 mice administered sRAGE (Figure 3D). However, sRAGE treatment in RAGE KO mice did not alter $\mathrm{T}_{\text {reg }} / \mathrm{T}_{\text {eff }}$ cell ratios in these lymphoid tissues (Figure 3E).

We interrogated expression of the proliferation marker $\mathrm{Ki67}$, as well as $\mathrm{T}_{\text {reg }}$ activation markers TIGIT, KLRG1, CD44 and CD62L (representative histograms and dot plots shown in Figure 3F) in the PLN and spleen of both wild-type and RAGE KO mice administered sRAGE. Consistent with the elevated $\mathrm{T}_{\text {reg }} / \mathrm{T}_{\text {eff }}$ cell ratios, the proportion of $\mathrm{CD} 4^{+} \mathrm{CD} 8^{-} \mathrm{CD} 25^{+} \mathrm{Foxp}^{+} \mathrm{T}_{\text {regs }}$ expressing Ki67 in wild-type mice had increased after sRAGE treatment, whereas CD4 ${ }^{+}$CD8- 
Mater Medical Research Institute Limited - Confidential

208 Foxp3- $^{-} \mathrm{T}_{\text {conv }}$ expression of $\mathrm{Ki} 67$ had declined (Figure $3 \mathrm{G}$ ). This suggested that $\mathrm{T}_{\text {reg }}$ proliferation

209 was a significant contributor to elevating the $\mathrm{T}_{\text {reg }} / \mathrm{T}_{\text {eff }}$ cell ratios, rather than other possible

210 scenarios such as improved $\mathrm{T}_{\text {reg }}$ emigration into the lymphoid tissues. $\mathrm{T}_{\text {reg }}$ TIGIT and KLRG1

211 expression were also elevated following sRAGE administration in wild-type mice (Figure 3G),

212 indicating the presence of activated and highly proliferative $\mathrm{T}_{\text {regs }}$ (Fuhrman et al., 2015). sRAGE

213 treated $\mathrm{T}_{\text {regs }}$ in wild-type mice also presented a more activated phenotype based on their

214 expression of the CD62L and CD44 adhesion molecules, with a reduced proportion of

$215 \mathrm{CD}_{2} \mathrm{~L}^{+} \mathrm{CD}_{4} 4^{-}$naïve $\mathrm{T}_{\text {regs, }}$ and an increased proportion of $\mathrm{CD}^{2} \mathrm{~L}^{-} \mathrm{CD}_{4} 4^{+}$effector and

$216 \mathrm{CD}_{2} \mathrm{~L}^{+} \mathrm{CD}_{4} 4^{+}$memory $\mathrm{T}_{\text {regs }}$ (Figure 3G). The expression of Ki67, TIGIT, KLRG1, CD62L and

217 CD44 were unchanged in the RAGE KO cohort following sRAGE therapy (Figure 3H).

218 Collectively, these data show that the activation and expansion of $\mathrm{T}_{\text {regs }}$ by sRAGE is dependent

219 on cellular RAGE expression, which improves the balance of $\mathrm{CD} 4^{+} \mathrm{CD} 8{ }^{-} \mathrm{CD} 25^{+} \mathrm{Foxp}^{+} \mathrm{T}_{\text {regs }}$ to

$220 \quad \mathrm{~T}_{\mathrm{eff}}$ cells in mice.

221 Targeted Reduction of Advanced Glycation End Products (AGEs) by sRAGE

222 sRAGE binds a variety of ligands implicated in the pathogenesis of T1D (Leung et al., 2016)

223 including the heterogeneous class of compounds named advanced glycation end products

224 (AGEs), high mobility group box 1 protein (HMGB1) and S100 calgranulins. To test if sRAGE

225 resulted in a targeted reduction of a particular ligand, we analyzed circulating concentrations of

226 these ligands in NOD/ShiLt mice. On day 64, immediately after sRAGE treatment, there were no

227 changes in the circulating concentrations of AGEs, including Ne-(carboxymethyl)lysine (CML),

228 Ne-(carboxyethyl)lysine (CEL) or methylglyoxal-derived hydroimidazolone (MG-H1; Table 1).

229 There were also no differences in the circulating AGE precursors methylglyoxal (MGO), glyoxal

230 (GO) or 3-deoxyglucosone (3-DG), immediately following sRAGE treatment (Table 1). 
Mater Medical Research Institute Limited - Confidential

231 However, on day 225, all plasma AGE concentrations were decreased in the sRAGE treated

232 group (vs. vehicle; Table 1). Plasma concentrations of other RAGE ligands, S100A8, S100A9,

233 S100B and HMGB1 did not differ between sRAGE and vehicle treated groups on either day 64

234 or 225 (Table 1). These findings support the hypothesis that sRAGE treatment results in a

235 targeted long-term reduction in the circulating ligand AGEs, which is associated with protection

236 against diabetes.

Islet Insulin and $\mathbf{T}_{\text {reg }}$ Proportions are Increased after sRAGE Treatment

We hypothesized that sRAGE could also increase the proportion of $\mathrm{T}_{\text {regs }}$ within pancreatic

islets, thereby providing local immunoregulation and a direct improvement in insulin expression.

240 We tested this by multiplexed immunofluorescence staining of pancreatic tissues in NOD/ShiLt

241 mice, which showed that $\mathrm{CD}^{+} \mathrm{CD}^{+} \mathrm{FoxP}^{+} \mathrm{T}_{\text {reg }}$ proportions were increased on both day 64 and

225 in the sRAGE treated mice (Figure 4A and 4C). Similarly, we observed an improvement in

insulin expression on both days 64 and 225 following sRAGE treatment (Figure 4B and 4C).

These improvements in insulin expression were significantly correlated with the proportion of expression.

Finally, we performed oral glucose tolerance tests (OGTTs) to assess if these improvements

248 in insulin expression would translate into functional improvements in glucose control. The 249 improvements in oral glucose tolerance emerged gradually, with no differences evident on day 25064 (Figure S5A-S5E), an increase in insulin secretion seen prediabetes on day 80 (Figure S5F251 S5J), and a marked improvement in glucose control and insulin action seen on day 225 (Figure 252 4E-4I). Specifically, on day 225, sRAGE treated mice had significantly lower fasting blood 253 glucose levels before the oral glucose bolos (vs. vehicle; Figure 4E), as well as lowered blood 
Mater Medical Research Institute Limited - Confidential

254 glucose concentrations at 15, 60 and 120 minutes post-glucose bolos (vs. vehicle; Figure 4E).

255 While the area under the curve for glucose $\left(\mathrm{AUC}_{\text {glucose }}\right)$, plasma insulin and the $\mathrm{AUC}_{\text {insulin }}$ did not 256 differ on day 225 (Figure $4 \mathrm{~F}-4 \mathrm{H}$ ), the $\mathrm{AUC}_{\text {glucose:insulin }}$ ratio, an indicator of insulin effectiveness, 257 was significantly lower in sRAGE treated mice (Figure 4I), suggesting an improvement in 258 insulin action. Altogether, these findings demonstrate that sRAGE increases $\mathrm{T}_{\text {regs }}$ and insulin 259 expression in the pancreatic islets, resulting in a persisting functional improvement in oral 260 glucose tolerance by the study end.

263 The circulating RAGE ligand, AGEs, are independent predictors for the development of T1D 264 in humans (Beyan et al., 2012) and sRAGE treatment led to a targeted decrease in circulating 265 AGEs (Table 1). Therefore, we hypothesized that AGEs directly bind human $\mathrm{T}_{\text {regs, influencing }}$ their proliferation and function. To this end, freshly isolated $\mathrm{CD} 3{ }^{+} \mathrm{CD} 3^{+} \mathrm{CD} 25^{+} \mathrm{CD} 127^{\mathrm{lo} /-}$ human

$267 \mathrm{~T}_{\text {regs }}$ (Figure S6A and S6B), of which $90.2 \pm 7.1 \%$ were positive for FoxP3 (Figure S6C and 268 S6D), were incubated with fluorescently labelled AGEs. These cells showed a time-dependent 269 increase in cellular fluorescence intensity (Figure 5A), indicative of binding and cellular uptake. 270 By contrast, co-administration of neutralizing anti-RAGE antibodies abrogated cellular 271 fluorescence from labelled AGEs (Figure 5A), suggesting that a significant amount of AGEs 272 bind to human $T_{\text {regs }}$ in a RAGE-dependent manner. Human $T_{\text {regs }}$ incubated with fluorescently 273 labelled human serum albumin (HSA) also had less cellular fluorescence, as compared with $\mathrm{T}_{\text {regs }}$ 274 incubated with AGEs, supporting the idea that AGE binding to human $\mathrm{T}_{\text {regs }}$ occurs is a RAGE specific mechanism (Figure 5A). 
Mater Medical Research Institute Limited - Confidential

We tested the effects of sRAGE on various conditions conducive to the proliferation or generation of human $\mathrm{T}_{\text {regs }}$ ex vivo. First, we co-cultured $\mathrm{CD}^{+} \mathrm{CD} 4^{+} \mathrm{CD} 25^{+} \mathrm{CD} 127^{\mathrm{lo} /-}$ natural $\mathrm{T}_{\text {regs }}$ (nT $\mathrm{T}_{\text {regs }}$ ) and $\mathrm{CD}^{+} \mathrm{CD}^{+} \mathrm{CD} 25^{-} \mathrm{T}_{\text {convs }}$ obtained by FACS from fresh human PBMCs (Figure $\mathrm{S} 6$ ), and labeled with CFSE or CellTrace Violet respectively, in the presence of the RAGE ligand AGEs, with or without sRAGE treatment (Figure 5B). Here, we found that sRAGE accelerated $\mathrm{nT}_{\text {reg }}$ proliferation whilst decreasing the proliferation index of $\mathrm{T}_{\text {convs }}$ (Figure 5B-5D). These effects occurred through PI3K-Akt-mTOR signaling since the addition of wortmannin and triciribine, inhibitors of this pathway, resulted in dose-dependent quenching of $\mathrm{nT}_{\text {reg }}$ proliferation (Figure 5B-5D). This is consistent with previous findings that show the proliferation of $\mathrm{nT}_{\text {regs }}$ requires PI3K-Akt-mTOR activation (Wang et al., 2011). Similarly, the proliferation of sRAGE treated $\mathrm{T}_{\text {conv }}$ cells was further decreased in the presence of wortmannin and triciribine (Figure 5B-5D). Altogether, this data supports a role for $\mathrm{sRAGE}$ in promoting $\mathrm{nT}_{\text {reg }}$ proliferation in coculture.

We also tested if sRAGE could promote the generation of induced $\mathrm{T}_{\text {regs }}\left(\mathrm{i} \mathrm{T}_{\text {regs }}\right)$. Here, $\mathrm{CD}^{+} \mathrm{CD}^{+} \mathrm{CD}^{2} 4 \mathrm{RA}^{+} \mathrm{CD} 45 \mathrm{RO}^{-}$naïve human $\mathrm{T}$ cells were isolated (Figure $\mathrm{S} 7 \mathrm{~A}$ and $\mathrm{S} 7 \mathrm{~B}$ ), stimulated as previously described (Ellis et al., 2012) in the presence of AGEs and analyzed for $\mathrm{iT}_{\text {reg }}$ differentiation (Figure S7C-S7E). In these conditions, sRAGE treatment led to a reduction in $\mathrm{iT}_{\text {reg }}$ generation (Figure $\mathrm{S} 8$ ), which suggests the differentiation of $\mathrm{iT}_{\text {regs }}$ does not contribute to increasing the overall population of $\mathrm{T}_{\text {regs }}$ after $\mathrm{sRAGE}$ treatment.

\section{AGEs Promote Human $\mathbf{n T}_{\text {reg }}$ Proliferation in Monoculture but Inhibit Suppressive}

\section{Function}

To further investigate the hypothesis that sRAGE maintains the proliferative balance between $\mathrm{nT}_{\text {regs }}$ and $\mathrm{T}_{\text {convs, }}$, we performed $\mathrm{nT}_{\text {reg }}$ monoculture experiments in the presence of AGEs with or 
Mater Medical Research Institute Limited - Confidential

without sRAGE administration (Figure 5E). Here, we found that sRAGE increased the mean fluorescence intensity (MFI) of CFSE labeled $\mathrm{nT}_{\text {regs }}$ (vs. vehicle; Figure 5E and 5F), suggesting that sRAGE inhibits the proliferation of $\mathrm{nT}_{\text {regs }}$ when other $\mathrm{T}$ cell populations are absent. This finding is consistent with previous studies where RAGE $\mathrm{KO}$ inhibits $\mathrm{T}_{\text {conv }}$ proliferation (Chen et al., 2008). To the best of our knowledge, however, there are no studies showing a role for RAGE in $\mathrm{nT}_{\text {reg }}$ proliferation. Here, our data supports a role for the RAGE ligand, AGEs, in promoting the proliferation of $\mathrm{nT}_{\text {regs }}$ cultured in isolation.

However, proliferation of $\mathrm{nT}_{\text {regs }}$ can be associated with a loss of suppressive function (Gerriets et al., 2016; Putnam et al., 2009), so we postulated that although AGEs induce the proliferation of $\mathrm{nT}_{\text {regs }}$ in the absence of other $\mathrm{T}$ cell populations, they limit their function. To test this, we performed human $\mathrm{nT}_{\text {reg }}$ monoculture experiments and quantified changes in gene expression using NanoString. Principal component analyses (PCA) distinctively separated the HSA (control) and AGE treated $\mathrm{nT}_{\text {regs }}$ (Figure 6A), particularly along principal component 1 (PC1) that accounted for $56 \%$ of the variance overall. HSA treated $\mathrm{nT}_{\text {regs }}$ were enriched in the expression of genes involved in $\mathrm{nT}_{\text {reg }}$ function (JAK1, IRF4, SOCS1; Figure 6A) (Cretney et al., 2011; Kirken et al., 1995; Takahashi et al., 2017), while AGE treatment decreased the expression of these functional $\mathrm{nT}_{\text {reg }}$ genes.

Differentially expressed genes were visualized by volcano plot (Figure 6B) where we found that $\mathrm{AGE}$ treated $\mathrm{nT}_{\text {regs }}$ had reduced expression of key $\mathrm{nT}_{\text {reg }}$ genes including FOXP3, IL7R, TIGIT and STAT5b (Cohen et al., 2006), as well as several other genes that promote $\mathrm{nT}_{\text {reg }}$ function (BACH2, CD96, IL10RA, JAK1/3, ITK, CD27, IRF4, STAT3/6, CD226) (Chaudhry et al., 2011; Cretney et al., 2011; Duggleby et al., 2007; Fuhrman et al., 2015; Huang et al., 2014; Kirken et al., 1995; Pallandre et al., 2007; Piedavent-Salomon et al., 2015; Roychoudhuri et al., 
Mater Medical Research Institute Limited - Confidential

2013; Sanchez-Guajardo et al., 2007) and migration (CCR4, AHR) (Gobert et al., 2009; Ye et al., 2017). Interestingly, $\mathrm{AGE}$ treated $\mathrm{nT}_{\text {regs }}$ also had changes in the expression of granzymes $\mathrm{A} / \mathrm{B} / \mathrm{K}$ and granulysin $(G Z M B, G Z M B, G Z M K, G N L Y)$ and decreased expression of EOMES (Figure 6B), a marker for T cell exhaustion.

Pathway enrichment analysis of genes downregulated by AGEs identified significant biological pathways including interleukin 7 and interleukin 2 family signaling, JAK/STAT signaling pathway, as well as the PDGF/EGFR signaling pathways (Figure 6C) that all play a role in maintaining $\mathrm{nT}_{\text {reg }}$ function (Lo Re et al., 2011; Wang et al., 2016). Ingenuity Pathway Analysis predicted 161 statistically significant upstream regulators associated with the changes in gene expression caused by AGE treatment (Figure 6D and Table S1). Of interest, the top ten upstream regulators included key $\mathrm{nT}_{\text {reg }}$ signaling molecules $(C D 28, I L 2, C D 3, S T A T 3, \mathrm{TCR})$ as well as other T cell associated proteins (IL4, TBX21, NPC2, CEBPB, GATA3; Figure 6D). These data are consistent with a role for the RAGE ligand, AGEs, in influencing crucial $\mathrm{nT}_{\text {reg }}$ signaling cascades. Finally, we performed network analysis, focusing on the most statistically significant network (Table S2), which identified neighboring nodes for FOXP3 and several genes upstream (IL10RA, STAT3/5B, NFATC2) and downstream (IL7R, CCR4) of FOXP3, which were changed in expression following AGE treatment (Figure 6E). Predicted upstream regulators after AGE treatment (CD3, TCR; Figure 6D) were also neighboring nodes with FOXP3 (Figure 6E). All other genes were either two or three nodes adjacent of FOXP3 (Figure 6E), highlighting the intimate cross-talk amongst genes influenced by $\mathrm{AGEs}$ and the $\mathrm{nT}_{\text {reg }}$ master regulatory gene FOXP3.

These data provide strong evidence that despite promoting human $\mathrm{nT}_{\text {reg }}$ proliferation in the absence of other $\mathrm{T}$ cell populations, AGE treatment results in a loss of suppressive function. 
bioRxiv preprint doi: https://doi.org/10.1101/2020 01.10.902627; this version posted January 11, 2020. The copyright holder for this preprint

(which was not certified by peer review) is the author/funder, who has granted bioRxiv a license to display the preprint in perpetuity. It is made available under aCC-BY-ND 4.0 International license.

Mater Medical Research Institute Limited - Confidential

345 These functional defects can be rescued by the competitive RAGE antagonist sRAGE in co-

346 culture where it expands functional human $\mathrm{nT}_{\text {regs }}$ that suppress $\mathrm{T}_{\text {conv }}$ proliferation. Taken together

347 with the efficacy of sRAGE to expand $T_{\text {regs }}$ and prevent diabetes in mice, we propose that

348 sRAGE therapy should be tested in at-risk individuals to prevent the onset of T1D. 
Mater Medical Research Institute Limited - Confidential

\section{Discussion}

There is an urgent unmet need for novel disease targets and treatments that are reproducible and have high potential to be translated to prevent T1D in humans (Insel et al., 2015). Here, we report that a RAGE antagonist sRAGE has a novel immunomodulatory role where it maintains the balance between $T_{\text {regs }}$ and $T_{\text {effs, }}$ a critical process in self-tolerance (Brusko et al., 2005). We show that sRAGE treatment in several mouse models resulted in increased $\mathrm{T}_{\text {reg }}$ ratios in the PLN and spleen, which are lymphoid tissues that have both been implicated in the pathogenesis of diabetes (McNally et al., 2011), as well as within the pancreatic islet immune cell infiltrate. Using human T cell culture, we found that sRAGE promoted the expansion of functional human $\mathrm{nT}_{\text {regs, }}$ whereas the RAGE ligand AGEs significantly impaired their suppressive function. Ultimately, we show that short-term intervention with sRAGE restored $\mathrm{T}_{\text {reg }} / \mathrm{T}_{\text {eff }}$ ratios, protecting against diabetes onset at two independent research centers.

Immediately after sRAGE therapy on day 64, islet infiltration was reduced, which was accompanied by increases in the absolute numbers of $\mathrm{T}_{\text {regs }}$ as well as $\mathrm{T}_{\text {reg }} / \mathrm{T}_{\text {eff }}$ ratios in the PLN. These changes in the PLN are critical for islet preservation and arresting disease progression, since $\mathrm{T}_{\text {regs }}$ localized here suppress the priming of autoantigen specific $\mathrm{T}$ cells (McNally et al., 2011), which would otherwise infiltrate the pancreatic islets. The transient increase in PLN leukocytes is consistent with previous work where sRAGE showed immunomodulatory effects on monocytes, macrophages and B cells (Pullerits et al., 2006). Here, we also found an increase in macrophage numbers following sRAGE treatment on day 64. Further investigation into their phenotype is warranted since changes in the macrophage transcriptome associates with T1D (Ferris et al., 2017). Interestingly, we report increased numbers of dendritic cell subsets within the spleen, but not the PLN, suggesting that they are not significant contributors in the expansion 
Mater Medical Research Institute Limited - Confidential

of $\mathrm{T}_{\text {regs }}$ within the major draining lymphoid tissue in T1D. In support of this, we also delineated that the modulation of $\mathrm{T}_{\text {regs }}$ specifically, using anti-FR4 antibodies to deplete $\mathrm{T}_{\text {regs, }}$ is critical for the protection afforded against diabetes by sRAGE. $\mathrm{T}_{\text {reg }}$ immunomodulation comparable to this has also been seen with other interventions that are lead candidates for the treatment of T1D (Sherry et al., 2011). Further development of sRAGE therapy to optimize the dosing regimen and therapeutic window is likely to result in even more efficacious outcomes, which will facilitate its competition with the current lead candidate agents. We also acknowledge that recombinant human sRAGE is unlikely to be immunogenic since it is an endogenous protein, but it would be worthwhile investigating if RAGE-specific autoantibodies were produced as a result of this treatment.

By day 80 , islet infiltration was modestly increased in sRAGE treated mice, which could reflect differences in the type of infiltrating immune cells present. Indeed, it is likely that there are increased numbers of infiltrating $\mathrm{T}_{\text {regs }}$ at this time point in sRAGE treated mice, but we highlight that this remains untested. In support of this hypothesis, we found that sRAGE treatment had increased the proportion of $\mathrm{T}_{\text {regs }}$ in the islets on days 64 and 225, which associated with reduced islet infiltration by the study end. By day 225, sRAGE treatment had also improved oral glucose tolerance and insulin expression to preserve pancreatic islet numbers, which reflects the protection against diabetes (Sosenko et al., 2012). Given that early short-term intervention with sRAGE improved the balance of $\mathrm{T}_{\text {regs, }}$ imparting persistent improvements in autoimmunity and glycemic control, this therapy shows promise in preventing the onset of clinical T1D.

Mice deficient in RAGE could not increase $\mathrm{T}_{\text {reg }} / \mathrm{T}_{\text {eff }}$ cell ratios within lymphoid tissues following sRAGE intervention, which alludes to the importance of cellular RAGE antagonism for the mechanism of this therapy. RAGE plays an important role in T cell survival (Durning et 
Mater Medical Research Institute Limited - Confidential

al., 2016) and proliferation (Chen et al., 2008), including in individuals at-risk of T1D, but there has been no delineation as to whether this applies to specific $\mathrm{T}$ cell subsets such as $\mathrm{T}_{\text {regs. }}$ Furthermore, there is no data examining whether RAGE impacts $\mathrm{T}_{\text {reg }}$ function. In the current study, we confirmed the expression of RAGE on $\mathrm{T}_{\text {regs }}$ in the PLN and spleen of NOD/ShiLt mice and found that sRAGE treatment improved localized $\mathrm{T}_{\text {reg }} / \mathrm{T}_{\text {eff }}$ ratios after therapy completion. In the long-term, sRAGE treated mice had reduced circulating concentrations of the heterogeneous class of RAGE ligands termed AGEs, including CML, CEL and MG-H1, and increased splenic $\mathrm{T}_{\text {reg }} / \mathrm{T}_{\text {eff }}$ cell ratios. Similarly, sRAGE increased $\mathrm{T}_{\text {reg }} / \mathrm{T}_{\text {eff }}$ ratios, as well as the expression of the $\mathrm{T}_{\text {reg }}$ activation markers Ki67, TIGIT, KLRG1 and CD44, in wild-type C57BL/6 but not RAGE KO mice. It was noteworthy that RAGE KO mice did not have changes in $\mathrm{T}_{\text {reg }} / \mathrm{T}_{\text {eff }}$ ratios as compared with WT mice prior to sRAGE treatment. This could suggest that long-term depletion of RAGE leads to the normalization of $\mathrm{T}_{\text {reg }} / \mathrm{T}_{\text {eff }}$ ratios, potentially by compensatory signaling through receptors which share ligands with RAGE such as toll-like receptors (TLRs). In support of this, crosstalk between RAGE and TLRs has been found to synergistically drive inflammation via NF- $\mathrm{BB}$ (Gasiorowski et al., 2018). However, as alluded to in this study, the function of $\mathrm{T}$ cells and $\mathrm{T}_{\text {regs }}$ in RAGE KO mice may be compromised.

In children who progress to T1D, circulating sRAGE concentrations are decreased prediabetes (Forbes et al., 2011; Salonen et al., 2015; Salonen et al., 2016) and increases in the RAGE ligand AGEs are independent predictors of progression to T1D (Beyan et al., 2012). To this end, shortterm sRAGE treatment facilitated long-lived decreases in circulating protein-bound AGEs (CML, CEL and MG-H1), alongside improved insulin expression and action in mice. We also demonstrated that AGEs promoted human $\mathrm{nT}_{\text {reg }}$ proliferation when these cells were cultured alone but this resulted in significant impairment of $n T_{\text {reg }}$ function. By contrast, $\mathrm{sRAGE}$ treatment 
Mater Medical Research Institute Limited - Confidential

418 led to the expansion of functional human $\mathrm{nT}_{\text {regs, }}$ since $\mathrm{sRAGE}$ increased the proliferation of

$419 \mathrm{nT}_{\text {regs }}$ that could inhibit $\mathrm{T}_{\text {conv }}$ cell division in co-culture.

420 We highlight the importance for future studies to perform the functional assays presented in 421 this study not only using healthy human $\mathrm{T}_{\text {regs, }}$, but also in $\mathrm{T}$ cells obtained from individuals with 422 presymptomatic and overt $\mathrm{T} 1 \mathrm{D}$, to expand our knowledge about the role of RAGE in $\mathrm{T}_{\text {reg }}$ 423 function in this disease context. Furthermore, the use of tetramer complexes could help confirm 424 if the effects observed on T cells in this study translate to changes in the numbers and function of 425 autoantigen-specific $\mathrm{T}$ cells and $\mathrm{T}_{\mathrm{regs}}$ that are known to affect $\mathrm{T} 1 \mathrm{D}$ pathogenesis. Finally, the use 426 of humanized mice with human umbilical cord blood stem cells or bone marrow, liver and 427 thymus ("BLT") transplants could further progress the therapeutic development of sRAGE by demonstrating its efficacy using an in vivo human immune system. Overall, RAGE and RAGE ligand biology clearly require further interrogation to better understand their contribution to 430 antigen-specific $\mathrm{T}$ cell and $\mathrm{T}_{\text {reg }}$ responses in T1D.

431 In summary, we have shown that sRAGE is an immunomodulatory compound and is an 432 important factor in balancing $\mathrm{T}_{\text {reg }}$ responses to their environment, including through the RAGE 433 ligand AGEs. This was ascertained using human $\mathrm{T}$ cell assays as well as using murine models 434 that were RAGE deficient or at high-risk of autoimmune diabetes, where the presence of 435 functional $\mathrm{T}_{\text {regs }}$ is known to be compromised. We showed that a short-term two-week 436 intervention with sRAGE elicited persistent effects on the immune system, ultimately preserving $437 \quad \beta$ cell function and reducing diabetes incidence in a multi-site preclinical trial. Given that 438 sRAGE is a native protein that is reduced in children at risk of T1D, and has persistent benefits 439 on insulin expression, oral glucose tolerance and $\mathrm{T}_{\text {reg }} / \mathrm{T}_{\text {eff }}$ ratios, we suggest that this treatment is 440 a promising new therapy for further development to prevent T1D. 
Mater Medical Research Institute Limited - Confidential

441

442

443

444

445

446

447

448

449

450

451

452

453

454

455

456

457

458

459

460

461

462

463

\section{Materials and Methods}

\section{Mice}

Female NOD/ShiLt mice were housed in specific pathogen-free conditions at two independent research centers - Site 1, Translational Research Institute, Brisbane, Australia; and Site 2, Type 1 Diabetes Research Center, Novo Nordisk, Seattle, US. Mice were sourced from The Animal Resources Centre (Canning Vale, Australia; Site 1) or The Jackson Laboratory (Sacramento, CA, US; Site 2), and were provided free access to irradiated diet (Site 1, Specialty Feeds Rat and Mouse Diet; Site 2, Purina Lab Diet 5053) and water (Site 1, autoclaved; Site 2, filtered). Sample size calculations were performed using $\alpha=0.05$ and a power of 0.80 , where $80 \%$ of the control mice were expected to develop diabetes by the study end as per historical data available in the animal facilities.

Female NOD/SCIDs, wild-type C57BL/6 and RAGE KO C57BL/6 (Liliensiek et al., 2004) mice were housed at Site 1. Animal studies were approved at both sites by their respective institutional ethics committees and adhered to national guidelines by the National Health and Medical Research Council (NHMRC, Australia) and NIH (US).

\section{Human Samples}

Human whole blood specimens were obtained by venipuncture using citrate-phosphatedextrose-adenine or EDTA anti-coagulants and transported to the laboratory within 1-2 hours. Human donors were healthy volunteers, 18-65 years of age and provided informed consent. Experiments were approved by the Mater Ethics Committee.

\section{SRAGE Therapy}

Randomized mice were intraperitoneally injected on days 50-64 of life with $100 \mu \mathrm{L}$ recombinant human sRAGE $(25 \mu \mathrm{g})$ twice daily (Sites 1 and 2), vehicle (PBS) twice daily (Site 
Mater Medical Research Institute Limited - Confidential

464

465

466

467

468

469

470

471

472

473

474

475

476

477

478

479

480

481

482

483

484

485

486

1), sRAGE (100 $\mu \mathrm{g})$ once daily (Site 2), or untreated (Site 2). Treatment dosages was based on previous studies using sRAGE, which were able to detect changes in end points using $25-100 \mu \mathrm{g}$ sRAGE per day (Pullerits et al., 2006; Wang et al., 2010). Recombinant sRAGE was produced using an insect cell and baculovirus expression system with the cloned sequence for human endogenous secretory RAGE (esRAGE; from herein, sRAGE). Recombinant sRAGE was isolated using size exclusion and affinity chromatography, and protein purity determined to be $>99 \%$ by SDS-PAGE and Western Blot. Endotoxin levels were 0.065 EU/mg (0.00325 EU/day and $0.0065 \mathrm{EU} /$ day for $25 \mu \mathrm{g}$ twice daily and $100 \mu \mathrm{g}$ once daily dosages, respectively) as determined by limulus amebocyte lysate (LAL) assay.

Mice were fasted for 4-6 h and euthanazed on day 64, 80 or for non-progressors on 225 of life. Non-fasted blood glucose concentrations were measured weekly using a glucometer (Site 1, SensoCard; Site 2, Bayer Contour USB) between days 50-225. Diabetes was diagnosed when this exceeded $15 \mathrm{mmol} / \mathrm{L}$ on consecutive days at which point these progressors left the study.

\section{Adoptive Transfer}

Splenocytes $\left(10^{7}\right)$ from untreated female NOD/ShiLt mice diagnosed with diabetes within seven days were intravenously injected $(200 \mu \mathrm{L})$ into 5-9 week old female NOD/SCID recipients (Leiter, 2001). Briefly, splenocytes were mechanically dissociated using $70 \mu \mathrm{m}$ filters, red cell lysis performed using ammonium-chloride-potassium (ACK) buffer (ThermoFisher) and splenocytes washed several times into serum-free mouse-tonicity PBS (MT-PBS) for injection in vivo. Randomized NOD/SCID mice were then administered the following treatments for two weeks post-adoptive transfer: (i) PBS and rat isotype control IgG2b antibodies (RTK4530; BioLegend), (ii) PBS and anti-FR4 antibodies (TH6; BioLegend) for the depletion of $\mathrm{T}_{\text {regs }}$ via their selective expression of FR4 (Yamaguchi et al., 2007), (iii) sRAGE and isotype control 
Mater Medical Research Institute Limited - Confidential

487

488

489

490

491

492

493

494

495

496

497

498

499

500

501

502

503

504

505

506

507

508

antibodies, or (iv) sRAGE and anti-FR4 antibodies. PBS and sRAGE (25 $\mu \mathrm{g})$ were given twice daily, as above. Isotype control and anti-FR4 antibodies (10 $\mu \mathrm{g}$ for both) were given on days 0 , 3, 7, 10 and 14, and endotoxin levels were $<0.01 \mathrm{EU} / \mu \mathrm{g}(<0.1 \mathrm{EU} /$ injection $)$ as determined by LAL assay. Diabetes was monitored and diagnosed as above.

\section{Oral Glucose Tolerance Tests (OGTTs)}

Mice were fasted for 4-6 $\mathrm{h}$ and administered a $2 \mathrm{~g} / \mathrm{kg}$ glucose bolus by intragastric gavage. At 0, 15, 30, 60 and 120 min post-glucose bolus, blood glucose and plasma insulin were measured by glucometer and ELISA (Crystal Chem), respectively.

\section{RAGE Ligand Assays}

Fasting plasma S100A8/A9 (R\&D DuoSet), S100B (Abbexa), and HMGB1 (Shino-Test) were measured by ELISA. Circulating AGEs and dicarbonyls were measured by liquid chromatography-tandem mass spectrometry (LC-MS/MS) as previously described (Scheijen and Schalkwijk, 2014).

\section{Islet Histology and Immunofluorescence Staining}

Formalin fixed tissue sections $(4-5 \mu \mathrm{m})$ were deparaffinized and rehydrated using standard techniques, then stained with H\&E, coverslipped in DPX and imaged on the VS1200 brightfield microscope (Olympus). Islet infiltration was assessed in a blinded fashion using an islet infiltration index from 0 to 1 (no infiltration to complete infiltration), and individual islets graded as $0,1,2,3$ or 4 (no infiltration to $>75 \%$ infiltration) as previously described.

For multiplexed immunofluorescence staining, antigen retrieval was performed using sodium citrate buffer ( $\mathrm{pH}$ 6). Non-specific binding was blocked using 10\% donkey serum at room temperature for 1 hour, then sections were incubated with rabbit anti-CD3 (SP7, Abcam), goat 
Mater Medical Research Institute Limited - Confidential

509

510

511

512

513

514

515

516

517

518

519

520

521

522

523

524

525

526

527

528

529

530

531

anti-CD4 (\#AF554, polyclonal; R\&D Systems) and biotinylated anti-FoxP3 (FJK-16s; eBioscience) antibodies overnight at $4^{\circ} \mathrm{C}$, followed by incubation with anti-rabbit IRDye $800 \mathrm{CW}$ (\#926-32213; Li-cor Biosciences), anti-goat AlexaFluor568 (\#A11057; ThermoFisher), and streptavidin-AlexaFluor647 (\#S32357; ThermoFisher) at room temperature for 1 hour. Sections were blocked again as described above, then incubated with rat anti-insulin antibody (182410;

R\&D Systems) overnight at $4{ }^{\circ} \mathrm{C}$, followed by incubation with anti-rat AlexaFluor488 (\#A21208) at room temperature for 1 hour. Sections were coverslipped in Fluoroshield with DAPI and images captured on the FV1200 confocal microscope (Olympus). Quantification was performed in a blinded fashion using ImageJ v2.0.0.

\section{Flow Cytometry and Cell Sorting}

Mouse spleen and PLN were mechanically dissociated into single cells using $40 \mu \mathrm{m}$ filters and red cell lysis performed using ACK buffer (ThermoFisher). Blocking was performed using antiCD16/CD32 antibodies (BD Biosciences) and cells were stained using antibodies against CD4 (RM4-5, BD Biosciences unless indicated), CD8 (53-6.7), CD11b (M1/70), CD11c (HL3), B220 (RA3-6B2), F4/80 (CI:A3-1; Bio-Rad), CD62L (MEL-14), CD44 (IM7), CD25 (PC61), FoxP3 (FJK-16s, eBioscience), TIGIT (1G9, BioLegend unless indicated), KLRG1 (2F1) and Ki67 (16A8). Samples were analyzed on the LSRII (BD Biosciences) and FlowJo (Tree Star Inc).

Human PBMCs were isolated by Ficoll and incubated with antibodies against CD3 (OKT3, BioLegend unless indicated), CD4 (RPA-T4), CD25 (BC96), CD127 (A019D5) and FoxP3 (PCH101; eBioscience). Dead cells were excluded using a Live/Dead viability dye (ThermoFisher) and blocking was performed using Human TruStain FcX (BioLegend). $\mathrm{CD}^{+} \mathrm{CD}^{+} \mathrm{CD} 25^{+} \mathrm{CD} 127^{\mathrm{lo} /-} \mathrm{nT}_{\text {regs }}$ and $\mathrm{CD}^{+} \mathrm{CD}^{+} \mathrm{CD} 25^{-} \mathrm{T}_{\text {convs }}$ were isolated on the Astrios (Beckman Coulter) or FACSAria (BD Biosciences) and analyzed using FlowJo $\left(>97 \% \mathrm{nT}_{\text {reg }}\right.$ and 
Mater Medical Research Institute Limited - Confidential

$532 \mathrm{~T}_{\text {conv }}$ purity). $\mathrm{CD}^{+} \mathrm{CD}^{+} \mathrm{CD} 25^{+} \mathrm{CD} 127^{\mathrm{lo} /-} \mathrm{nT}$ regs were $90.2 \pm 7.1 \%$ FoxP3 positive using human

533 PBMCs (Figure S6C and S6D), consistent with previous studies which have examined the use of

$534 \mathrm{CD}^{+} \mathrm{CD}^{+} \mathrm{CD} 25^{+} \mathrm{CD} 127^{\mathrm{lo} /-}$ cells for isolating live, viable $\mathrm{nT}_{\text {regs }}$ for ex vivo assays (Putnam et al., 535 2009).

536

\section{Human T Cell Culture}

Human $\mathrm{nT}_{\text {regs }}$ were CFSE labelled and cultured in TexMACs (Miltenyi Biotec) supplemented with 10\% heat inactivated fetal bovine serum (HI-FBS, Life Technologies unless indicated), 100 $\mathrm{U} / \mathrm{mL}$ penicillin-streptomycin, $10 \mu \mathrm{M} \beta$-mercaptoethanol and $100 \mu \mathrm{g} / \mathrm{mL}$ AGE-modified HSA (AGE-HSA or AGE) at a final number of $2.5 \times 10^{4}$ cells in a U-bottom 96-well plate. $\mathrm{T}_{\text {convs }}$ were CellTrace Violet labelled and added to a final number of $2.5 \times 10^{4}$ cells. Cells were stimulated using anti-CD3/CD28 MACSiBeads at a 1:10 bead-to-cell ratio. Co-cultures were treated with $50 \mu \mathrm{g}$ sRAGE or PBS daily, for $72 \mathrm{~h}$ at $37^{\circ} \mathrm{C} / 5 \% \mathrm{CO}_{2}$. Proliferation was analyzed using CFSE and CellTrace Violet dye dilution on the LSRFortessa (BD Biosciences) and FlowJo.

CFSE labeled human $\mathrm{nT}_{\text {regs }}$ were also grown in monoculture using TexMACs supplemented with 10\% HI-FBS, $100 \mathrm{U} / \mathrm{mL}$ penicillin-streptomycin, $10 \mu \mathrm{M} \beta$-mercaptoethanol and $200 \mathrm{IU} / \mathrm{mL}$ IL-2 at a final number of $2 \times 10^{4}$ cells in a U-bottom 96-well plate. Cells were stimulated using anti-CD3/CD28 MACSiBeads at a 1:20 bead-to-cell ratio. Cells were treated with $100 \mathrm{ug} / \mathrm{mL}$ HSA or AGEs for $72 \mathrm{~h}$ at $37^{\circ} \mathrm{C} / 5 \% \mathrm{CO}_{2}$, and analyzed as above.

For gene expression analysis, unlabeled $\mathrm{nT}_{\text {regs }}$ were grown in monoculture under the conditions as described above for $72 \mathrm{~h}$ and anti-CD3/CD28 MACSiBeads removed by EasySep Magnet. RNA was isolated using RNAzol RT (Astral Scientific) per manufacturer's instructions with the use of molecular grade isopropanol and ethanol (Sigma Aldrich) for RNA precipitation. Briefly, cells were lysed and centrifuged to separate the aqueous phase which contained RNA. 
Mater Medical Research Institute Limited - Confidential

555

556

557

558

559

560

561

562

563

564

565

566

567

568

569

570

571

572

573

574

Multiple ethanol washes were performed before resuspension of the purified RNA pellet. RNA quality and quantity were probed using an Implen NanoPhotometer N60 (LabGear). 100 ng RNA

was hybridized overnight using a NanoString Custom CodeSet for $136 \mathrm{~T}$ cell specific genes.

Normalization of raw counts was performed using NanoString NSolver software with the housekeeping genes $A C T B, B 2 M, G A P D H, H P R T 1$ and RPLP0 (panel in Table S3).

Naïve $\mathrm{CD}^{+} \mathrm{T}$ cells were negatively isolated from fresh PBMCs by EasySep (Stem Cell Technologies; $>95 \%$ purity). Cells were stimulated (Ellis et al., 2012), treated with $100 \mu \mathrm{g} / \mathrm{mL}$ AGEs and $50 \mu \mathrm{g}$ sRAGE or PBS daily for $72 \mathrm{~h}$ at $37{ }^{\circ} \mathrm{C} / 5 \% \mathrm{CO}_{2}$, and analyzed for $\mathrm{CD}^{+} \mathrm{CD}^{+} \mathrm{CD} 25^{+} \mathrm{CD} 127^{\mathrm{lo} /}-\mathrm{iT}_{\text {reg }}$ differentiation on the LSRFortessa (BD Biosciences) and FlowJo.

\section{AGE-HSA Production}

AGE-HSA was produced by incubating $20 \mathrm{mg} / \mathrm{mL}$ fatty acid-free, cold ethanol precipitated human serum albumin (Sigma) and 0.5 M D-(+)-glucose (Sigma) in HyClone PBS (GE Healthcare) for 3 months at $37^{\circ} \mathrm{C}$ in the dark. Solutions were dialyzed in PBS (GE Healthcare) with 10K MWCO Slide-A-Lyzer Cassettes (ThermoFisher), $0.22 \mu \mathrm{m}$ filtered and stored at $-80^{\circ} \mathrm{C}$.

Endotoxins were determined to be $<1 \mathrm{EU} / \mathrm{mL}(<0.005 \mathrm{EU} / \mathrm{mL}$ at final concentrations in human cell culture experiments) by Limulus Amebocyte Lysate Assay. Quantification of AGE-HSA glycation adducts - RAGE ligands - was performed using LC-MS/MS as described above, producing the following concentrations: 646,568 nM CML, 45,279 nM CEL and 198,454 nM MG-H1 (28-, 22- and 11fold increases in glycation adduct concentrations respectively, as compared with unmodified HSA).

\section{Human nT reg Binding Assay}

Human $\mathrm{nT}_{\text {regs }}$ were stained using Hoechst 33342 (ThermoFisher) and cultured in phenol-free RPMI-1640 (ThermoFisher) in glass chambers and administered $100 \mu \mathrm{g} / \mathrm{mL}$ HSA- 
Mater Medical Research Institute Limited - Confidential

AlexaFluor488, AGE-AlexaFluor488, or AGE-AlexaFluor488 and anti-RAGE antibody (\#AB5484, Merck) for the durations indicated. Cells were imaged on the FV1200 confocal microscope and quantification was performed in a blinded fashion using ImageJ.

\section{Quantification and Statistical Analysis}

Statistical analyses were performed using GraphPad v5.01 and $P<0.05$ was considered statistically significant. Comparisons were done using biological not technical replicates which are shown in all figures. Normality was tested by Kolmogorov-Smirnov test. Means were compared by two-tailed Student's t-test and shown as mean \pm SD. Medians were compared by two-tailed Mann-Whitney U-test and shown as median (IQR). Kaplan-Meier survival curves were compared by log-rank test. Regression lines were compared by ANCOVA. Proportions were compared by Fischer's test. Gene expression was analyzed using R v.3.4.4 for PCA and volcano plots, DAVID v.6.8 for Reactome Pathway enrichment, PANTHER v.14.0 for Gene Ontology overrepresentation and Ingenuity Pathway Analysis v.1.14 for identification of upstream regulators and network analysis $(P$ values were adjusted using false discovery rate or Bonferroni). 
Mater Medical Research Institute Limited - Confidential

Author Contributions: SSL designed and performed experiments, analyzed and interpreted data and prepared the manuscript. DJB, DAMc, AZ, AKF, NF, TW, JJM, JLS and CGS performed experiments. TEB designed and JC performed the incidence experiment at the second site and both completed its data analyses and interpretation. KJR assisted with the human study design and completion. RJS, P-HG, MK, led by JMF conceptualized and designed the overall study, gained financial support and completed data analyses and interpretation. All authors edited and approved the final manuscript.

Competing Interests: P-HG is a board member of AbbVie, AstraZeneca, Boehringer Ingelheim, Cebix, Eli Lilly, Janssen, Medscape, Novartis, Novo Nordisk and Sanofi. P-HG received lecture honoraria from AstraZeneca, Boehringer Ingelheim, Eli Lilly, Genzyme, MSD, Novartis, Novo Nordisk and Sanofi. P-HG received grants from Eli Lilly and Roche. MK is a board member and minor $(<5 \%)$ shareholder of Vactech Ltd. MK received lecture honoraria from Novo Nordisk. TEB and JC received income and research support from Novo Nordisk.

Funding: This work was supported by the NHMRC (1023661), JDRF (5-2010-163), Diabetes Australia, The Victorian Government Infrastructure Program and Mater Foundation. SSL was supported by the Research Training Program and JDRF; AKF and NF by the Research Training Program; AZ by Kidney Health Australia; RJS by an ARC Fellowship (FT110100372); and JMF by NHMRC Fellowships (1004503, 1102935).

Acknowledgments: The authors thank I. Rojas and S. Diaz-Guilas for assistance with human cell culture; C. O'Brien and T. Friesen for assistance with the incidence study at Site 2; I. Buckle, J. Naranjo and E. Hamilton-Williams for providing diabetic NODs for the adoptive transfer; J. Lynch and S. Phipps for providing RAGE KO mice for exploratory analyses; K. MacDonald for feedback on $\mathrm{T}_{\text {reg }}$ experiments; E. Williams and the Australian Equine Genetics 
bioRxiv preprint doi: https://doi.org/10.1101/2020.01.10.902627; this version posted January 11, 2020. The copyright holder for this preprint (which was not certified by peer review) is the author/funder, who has granted bioRxiv a license to display the preprint in perpetuity. It is made available under aCC-BY-ND 4.0 International license.

Mater Medical Research Institute Limited - Confidential

616 Research Centre for assistance with the RAGE KO mice; and the Biological Resources, Flow

617 Cytometry, Histology and Microscopy facilities at the Translational Research Institute. 
Mater Medical Research Institute Limited - Confidential

618

619

620

621

622

623

624

625

626

627

628

629

630

631

632

633

634

635

636

637

638

639

640

\section{References}

Alhadj Ali, M., Liu, Y.F., Arif, S., Tatovic, D., Shariff, H., Gibson, V.B., Yusuf, N., Baptista, R., Eichmann, M., Petrov, N., et al. (2017). Metabolic and immune effects of immunotherapy with proinsulin peptide in human new-onset type 1 diabetes. Sci. Transl. Med. 9.

Atkinson, M.A., Eisenbarth, G.S., and Michels, A.W. (2014). Type 1 diabetes. Lancet 383, 69-

82.

Beyan, H., Riese, H., Hawa, M.I., Beretta, G., Davidson, H.W., Hutton, J.C., Burger, H.,

Schlosser, M., Snieder, H., Boehm, B.O., et al. (2012). Glycotoxin and autoantibodies are additive environmentally determined predictors of type 1 diabetes: a twin and population study.

Diabetes 61, 1192-1198.

Brusko, T.M., Wasserfall, C.H., Clare-Salzler, M.J., Schatz, D.A., and Atkinson, M.A. (2005).

Functional defects and the influence of age on the frequency of CD4+ CD25+ T-cells in type 1 diabetes. Diabetes 54, 1407-1414.

Chaudhry, A., Samstein, R.M., Treuting, P., Liang, Y., Pils, M.C., Heinrich, J.M., Jack, R.S., Wunderlich, F.T., Bruning, J.C., Muller, W., et al. (2011). Interleukin-10 signaling in regulatory T cells is required for suppression of Th17 cell-mediated inflammation. Immunity 34, 566-578.

Chen, Y., Akirav, E.M., Chen, W., Henegariu, O., Moser, B., Desai, D., Shen, J.M., Webster, J.C., Andrews, R.C., Mjalli, A.M., et al. (2008). RAGE ligation affects T cell activation and controls T cell differentiation. J. Immunol. 181, 4272-4278.

Cohen, A.C., Nadeau, K.C., Tu, W., Hwa, V., Dionis, K., Bezrodnik, L., Teper, A., Gaillard, M., Heinrich, J., Krensky, A.M., et al. (2006). Cutting edge: Decreased accumulation and regulatory function of CD4+ CD25(high) T cells in human STAT5b deficiency. J. Immunol. 177, 27702774. 
Mater Medical Research Institute Limited - Confidential

641 Cretney, E., Xin, A., Shi, W., Minnich, M., Masson, F., Miasari, M., Belz, G.T., Smyth, G.K.,

642 Busslinger, M., Nutt, S.L., et al. (2011). The transcription factors Blimp-1 and IRF4 jointly

643 control the differentiation and function of effector regulatory T cells. Nat Immunol 12, 304-311.

644 Das, N., Dewan, V., Grace, P.M., Gunn, R.J., Tamura, R., Tzarum, N., Watkins, L.R., Wilson,

645 I.A., and Yin, H. (2016). HMGB1 Activates Proinflammatory Signaling via TLR5 Leading to

646 Allodynia. Cell reports 17, 1128-1140.

647 Duggleby, R.C., Shaw, T.N., Jarvis, L.B., Kaur, G., and Gaston, J.S. (2007). CD27 expression

648 discriminates between regulatory and non-regulatory cells after expansion of human peripheral

649 blood CD4+ CD25+ cells. Immunology 121, 129-139.

650 Durning, S.P., Preston-Hurlburt, P., Clark, P.R., Xu, D., Herold, K.C., and Type 1 Diabetes

651 TrialNet Study Group (2016). The Receptor for Advanced Glycation Endproducts Drives T Cell

652 Survival and Inflammation in Type 1 Diabetes Mellitus. J. Immunol. 197, 3076-3085.

653 Ellis, G.I., Reneer, M.C., Velez-Ortega, A.C., McCool, A., and Marti, F. (2012). Generation of

654 induced regulatory $\mathrm{T}$ cells from primary human naive and memory $\mathrm{T}$ cells. Journal of visualized

655 experiments : JoVE.

656 Ferris, S.T., Zakharov, P.N., Wan, X., Calderon, B., Artyomov, M.N., Unanue, E.R., and

657 Carrero, J.A. (2017). The islet-resident macrophage is in an inflammatory state and senses

658 microbial products in blood. J. Exp. Med. 214, 2369-2385.

659 Forbes, J.M., Soderlund, J., Yap, F.Y., Knip, M., Andrikopoulos, S., Ilonen, J., Simell, O.,

660 Veijola, R., Sourris, K.C., Coughlan, M.T., et al. (2011). Receptor for advanced glycation end-

661 products (RAGE) provides a link between genetic susceptibility and environmental factors in

662 type 1 diabetes. Diabetologia 54, 1032-1042. 
Mater Medical Research Institute Limited - Confidential

663 Fuhrman, C.A., Yeh, W.I., Seay, H.R., Saikumar Lakshmi, P., Chopra, G., Zhang, L., Perry,

664 D.J., McClymont, S.A., Yadav, M., Lopez, M.C., et al. (2015). Divergent Phenotypes of Human

665 Regulatory T Cells Expressing the Receptors TIGIT and CD226. J. Immunol. 195, 145-155.

666 Gasiorowski, K., Brokos, B., Echeverria, V., Barreto, G.E., and Leszek, J. (2018). RAGE-TLR

667 Crosstalk Sustains Chronic Inflammation in Neurodegeneration. Mol. Neurobiol. 55, 1463-1476.

668 Gerriets, V.A., Kishton, R.J., Johnson, M.O., Cohen, S., Siska, P.J., Nichols, A.G., Warmoes,

669 M.O., de Cubas, A.A., MacIver, N.J., Locasale, J.W., et al. (2016). Foxp3 and Toll-like receptor

670 signaling balance Treg cell anabolic metabolism for suppression. Nat Immunol 17, 1459-1466.

671 Gobert, M., Treilleux, I., Bendriss-Vermare, N., Bachelot, T., Goddard-Leon, S., Arfi, V., Biota,

672 C., Doffin, A.C., Durand, I., Olive, D., et al. (2009). Regulatory T cells recruited through

673 CCL22/CCR4 are selectively activated in lymphoid infiltrates surrounding primary breast tumors

674 and lead to an adverse clinical outcome. Cancer Res 69, 2000-2009.

675 Herold, K.C., Bundy, B.N., Long, S.A., Bluestone, J.A., DiMeglio, L.A., Dufort, M.J., Gitelman,

676 S.E., Gottlieb, P.A., Krischer, J.P., Linsley, P.S., et al. (2019). An Anti-CD3 Antibody,

677 Teplizumab, in Relatives at Risk for Type 1 Diabetes. N. Engl. J. Med. 381, 603-613.

678 Huang, W., Jeong, A.R., Kannan, A.K., Huang, L., and August, A. (2014). IL-2-inducible T cell

679 kinase tunes T regulatory cell development and is required for suppressive function. J. Immunol.

$680 \quad 193,2267-2272$.

681 Insel, R.A., Dunne, J.L., Atkinson, M.A., Chiang, J.L., Dabelea, D., Gottlieb, P.A., Greenbaum,

682 C.J., Herold, K.C., Krischer, J.P., Lernmark, A., et al. (2015). Staging presymptomatic type 1

683 diabetes: a scientific statement of JDRF, the Endocrine Society, and the American Diabetes

684 Association. Diabetes Care 38, 1964-1974. 
Mater Medical Research Institute Limited - Confidential

685

686

687

688

689

690

691

692

693

694

695

696

697

698

699

700

701

702

703

704

705

706

Kirken, R.A., Rui, H., Malabarba, M.G., Howard, O.M., Kawamura, M., O'Shea, J.J., and Farrar, W.L. (1995). Activation of JAK3, but not JAK1, is critical for IL-2-induced proliferation and STAT5 recruitment by a COOH-terminal region of the IL-2 receptor beta-chain. Cytokine 7, 689-700.

Laban, S., Suwandi, J.S., van Unen, V., Pool, J., Wesselius, J., Hollt, T., Pezzotti, N., Vilanova, A., Lelieveldt, B.P.F., and Roep, B.O. (2018). Heterogeneity of circulating CD8 T-cells specific to islet, neo-antigen and virus in patients with type 1 diabetes mellitus. PloS One 13, e0200818. Leiter, E.H. (2001). The NOD mouse: a model for insulin-dependent diabetes mellitus. Curr. Protoc. Immunol. Chapter 15, Unit 1519.

Leung, S.S., Forbes, J.M., and Borg, D.J. (2016). Receptor for advanced glycation end products (RAGE) in type 1 diabetes pathogenesis. Curr. Diab. Rep. 16, 100.

Liliensiek, B., Weigand, M.A., Bierhaus, A., Nicklas, W., Kasper, M., Hofer, S., Plachky, J., Grone, H.J., Kurschus, F.C., Schmidt, A.M., et al. (2004). Receptor for advanced glycation end products (RAGE) regulates sepsis but not the adaptive immune response. J. Clin. Investig. 113, 1641-1650.

Lippens, C., Duraes, F.V., Dubrot, J., Brighouse, D., Lacroix, M., Irla, M., Aubry-Lachainaye, J.P., Reith, W., Mandl, J.N., and Hugues, S. (2016). IDO-orchestrated crosstalk between pDCs and Tregs inhibits autoimmunity. Journal of autoimmunity 75, 39-49.

Lo Re, S., Lecocq, M., Uwambayinema, F., Yakoub, Y., Delos, M., Demoulin, J.B., Lucas, S., Sparwasser, T., Renauld, J.C., Lison, D., et al. (2011). Platelet-derived growth factor-producing CD4+ Foxp3+ regulatory T lymphocytes promote lung fibrosis. Am J Respir Crit Care Med 184, $1270-1281$. 
Mater Medical Research Institute Limited - Confidential

McNally, A., Hill, G.R., Sparwasser, T., Thomas, R., and Steptoe, R.J. (2011). CD4+CD25+ regulatory T cells control CD8+ T-cell effector differentiation by modulating IL-2 homeostasis.

Proc. Natl. Acad. Sci. U. S. A. 108, 7529-7534.

Pallandre, J.R., Brillard, E., Crehange, G., Radlovic, A., Remy-Martin, J.P., Saas, P., Rohrlich, P.S., Pivot, X., Ling, X., Tiberghien, P., et al. (2007). Role of STAT3 in CD4+CD25+FOXP3+ regulatory lymphocyte generation: implications in graft-versus-host disease and antitumor immunity. J. Immunol. 179, 7593-7604.

Piedavent-Salomon, M., Willing, A., Engler, J.B., Steinbach, K., Bauer, S., Eggert, B., Ufer, F., Kursawe, N., Wehrmann, S., Jager, J., et al. (2015). Multiple sclerosis associated genetic variants of CD226 impair regulatory T cell function. Brain 138, 3263-3274.

Price, J.D., Beauchamp, N.M., Rahir, G., Zhao, Y., Rieger, C.C., Lau-Kilby, A.W., and Tarbell, K.V. (2014). CD8+ dendritic cell-mediated tolerance of autoreactive CD4+ T cells is deficient in NOD mice and can be corrected by blocking CD40L. J. Leukoc. Biol. 95, 325-336.

Pullerits, R., Brisslert, M., Jonsson, I.M., and Tarkowski, A. (2006). Soluble receptor for advanced glycation end products triggers a proinflammatory cytokine cascade via beta2 integrin Mac-1. Arthritis and rheumatism 54, 3898-3907.

Putnam, A.L., Brusko, T.M., Lee, M.R., Liu, W., Szot, G.L., Ghosh, T., Atkinson, M.A., and Bluestone, J.A. (2009). Expansion of human regulatory T-cells from patients with type 1 diabetes. Diabetes 58, 652-662.

Rosenzwajg, M., Churlaud, G., Mallone, R., Six, A., Derian, N., Chaara, W., Lorenzon, R., Long, S.A., Buckner, J.H., Afonso, G., et al. (2015). Low-dose interleukin-2 fosters a dosedependent regulatory T cell tuned milieu in T1D patients. J. Autoimmun. 58, 48-58. 
Mater Medical Research Institute Limited - Confidential

Roychoudhuri, R., Hirahara, K., Mousavi, K., Clever, D., Klebanoff, C.A., Bonelli, M., Sciume, G., Zare, H., Vahedi, G., Dema, B., et al. (2013). BACH2 represses effector programs to stabilize T(reg)-mediated immune homeostasis. Nature 498, 506-510.

Salonen, K.M., Ryhanen, S.J., Forbes, J.M., Borg, D.J., Harkonen, T., Ilonen, J., Simell, O., Veijola, R., Groop, P.H., and Knip, M. (2015). Decrease in circulating concentrations of soluble receptors for advanced glycation end products at the time of seroconversion to autoantibody positivity in children with prediabetes. Diabetes Care 38, 665-670.

Salonen, K.M., Ryhanen, S.J., Forbes, J.M., Harkonen, T., Ilonen, J., Laine, A.P., Groop, P.H., Knip, M., and Finnish Pediatric Diabetes Register (2014). Circulating concentrations of soluble receptor for AGE are associated with age and AGER gene polymorphisms in children with newly diagnosed type 1 diabetes. Diabetes Care 37, 1975-1981.

Salonen, K.M., Ryhanen, S.J., Forbes, J.M., Harkonen, T., Ilonen, J., Simell, O., Veijola, R., Groop, P.H., and Knip, M. (2016). A drop in the circulating concentrations of soluble receptor for advanced glycation end products is associated with seroconversion to autoantibody positivity but not with subsequent progression to clinical disease in children en route to type 1 diabetes. Diabetes-Metab. Res. Rev.

Sanchez-Guajardo, V., Tanchot, C., O'Malley, J.T., Kaplan, M.H., Garcia, S., and Freitas, A.A. (2007). Agonist-driven development of CD4+CD25+Foxp3+ regulatory T cells requires a second signal mediated by Stat6. J. Immunol. 178, 7550-7556.

Scheijen, J.L., and Schalkwijk, C.G. (2014). Quantification of glyoxal, methylglyoxal and 3deoxyglucosone in blood and plasma by ultra performance liquid chromatography tandem mass spectrometry: evaluation of blood specimen. Clinical chemistry and laboratory medicine 52, 8591. 
Mater Medical Research Institute Limited - Confidential

752

753

754

755

756

757

758

759

760

761

762

763

764

765

766

767

768

769

770

771

772

773
Sherry, N., Hagopian, W., Ludvigsson, J., Jain, S.M., Wahlen, J., Ferry, R.J., Jr., Bode, B.,

Aronoff, S., Holland, C., Carlin, D., et al. (2011). Teplizumab for treatment of type 1 diabetes

(Protege study): 1-year results from a randomised, placebo-controlled trial. Lancet 378, 487-497.

Sosenko, J.M., Skyler, J.S., Herold, K.C., Palmer, J.P., Type 1 Diabetes TrialNet, and Diabetes

Prevention Trial-Type 1 Study Groups (2012). The metabolic progression to type 1 diabetes as

indicated by serial oral glucose tolerance testing in the Diabetes Prevention Trial-type 1.

Diabetes 61, 1331-1337.

Takahashi, R., Nakatsukasa, H., Shiozawa, S., and Yoshimura, A. (2017). SOCS1 Is a Key

Molecule That Prevents Regulatory T Cell Plasticity under Inflammatory Conditions. J.

Immunol. 199, 149-158.

Tao, B., Pietropaolo, M., Atkinson, M., Schatz, D., and Taylor, D. (2010). Estimating the cost of type 1 diabetes in the U.S.: a propensity score matching method. PloS One 5, e11501.

Tordesillas, L., Lozano-Ojalvo, D., Dunkin, D., Mondoulet, L., Agudo, J., Merad, M., Sampson, H.A., and Berin, M.C. (2018). PDL2(+) CD11b(+) dermal dendritic cells capture topical antigen through hair follicles to prime LAP(+) Tregs. Nat Commun 9, 5238.

Wang, S., Zhang, Y., Wang, Y., Ye, P., Li, J., Li, H., Ding, Q., and Xia, J. (2016). Amphiregulin Confers Regulatory T Cell Suppressive Function and Tumor Invasion via the EGFR/GSK3beta/Foxp3 Axis. J Biol Chem 291, 21085-21095.

Wang, Y., Camirand, G., Lin, Y., Froicu, M., Deng, S., Shlomchik, W.D., Lakkis, F.G., and Rothstein, D.M. (2011). Regulatory T cells require mammalian target of rapamycin signaling to maintain both homeostasis and alloantigen-driven proliferation in lymphocyte-replete mice. J.

Immunol. 186, 2809-2818. 
Mater Medical Research Institute Limited - Confidential

774 Wang, Y., Wang, H., Piper, M.G., McMaken, S., Mo, X., Opalek, J., Schmidt, A.M., and Marsh,

775 C.B. (2010). sRAGE induces human monocyte survival and differentiation. J. Immunol. 185,

$776 \quad 1822-1835$.

777 Yamaguchi, T., Hirota, K., Nagahama, K., Ohkawa, K., Takahashi, T., Nomura, T., and

778 Sakaguchi, S. (2007). Control of immune responses by antigen-specific regulatory T cells

779 expressing the folate receptor. Immunity $27,145-159$.

780 Yamazaki, S., Dudziak, D., Heidkamp, G.F., Fiorese, C., Bonito, A.J., Inaba, K., Nussenzweig,

781 M.C., and Steinman, R.M. (2008). CD8+CD205+ splenic dendritic cells are specialized to

782 induce Foxp3+ regulatory T cells. Journal of immunology 181, 6923-6933.

783 Ye, J., Qiu, J., Bostick, J.W., Ueda, A., Schjerven, H., Li, S., Jobin, C., Chen, Z.E., and Zhou, L.

784 (2017). The Aryl Hydrocarbon Receptor Preferentially Marks and Promotes Gut Regulatory T

785 Cells. Cell reports 21, 2277-2290. 
bioRxiv preprint doi: https://doi.org/10.1101/2020.01.10.902627; this version posted January 11,2020 . The copyright holder for this preprint (which was not certified by peer review) is the author/funder, who has granted bioRxiv a license to display the preprint in perpetuity. It is made available under aCC-BY-ND 4.0 International license.

Mater Medical Research Institute Limited - Confidential

Figures
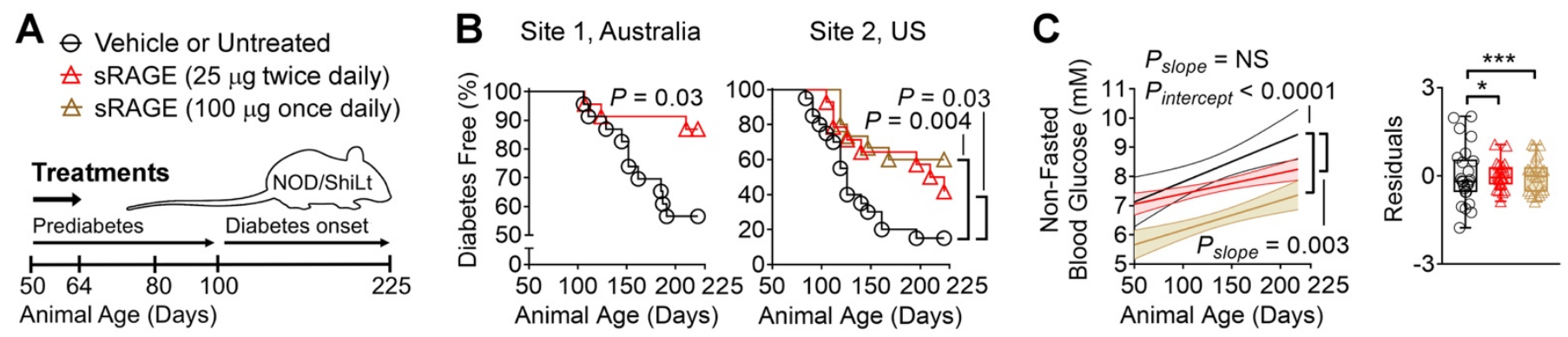

D
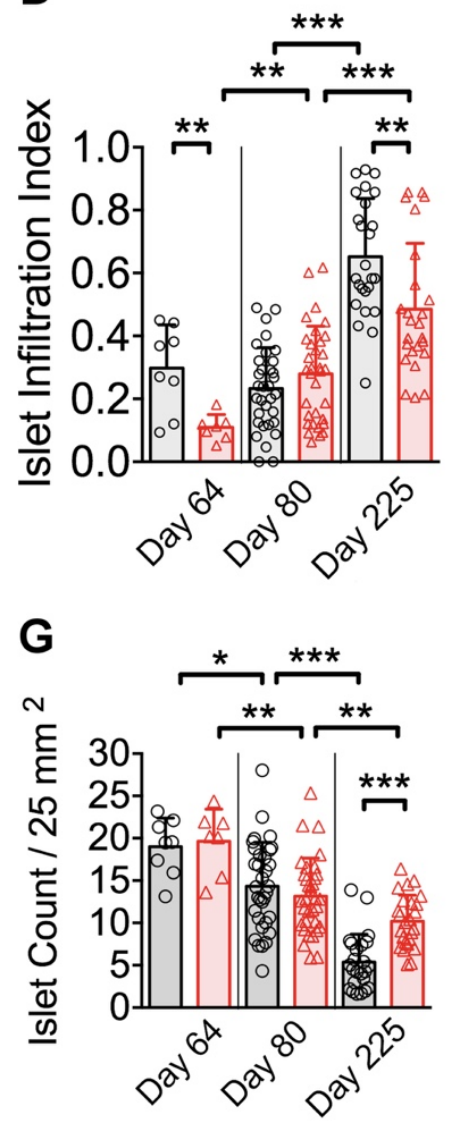

$\mathbf{E}$

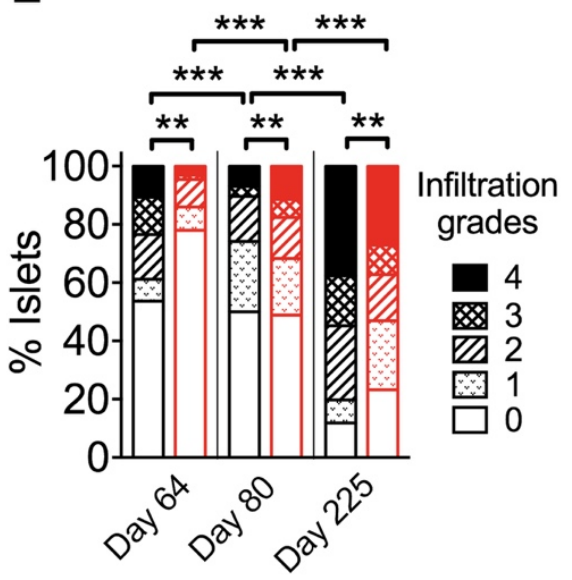

F Vehicle
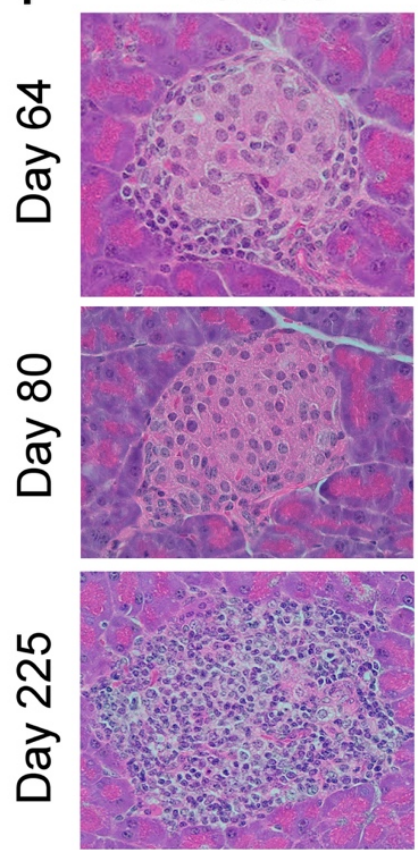

sRAGE

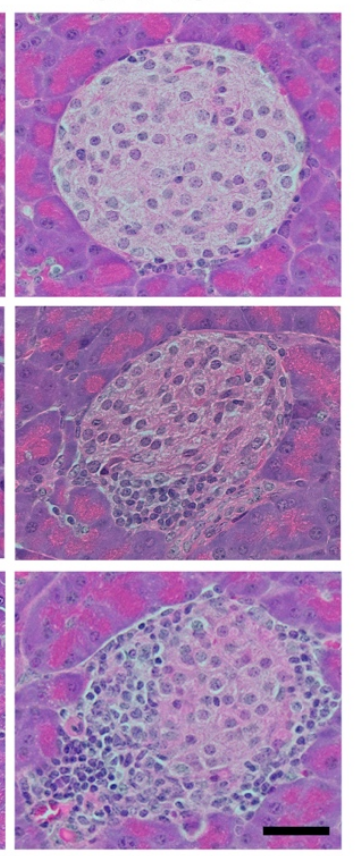

Figure 1. Treatment with sRAGE provides lasting protection against autoimmune diabetes in an

\section{international multi-site preclinical trial.}

(A) NOD/ShiLt mice were administered vehicle at Site 1 or untreated at Site 2 (black bars/circles), or treated with $25 \mu \mathrm{g}$ sRAGE twice daily (red bars/triangles) or $100 \mu \mathrm{g}$ sRAGE once daily (brown bars/triangles) from days 50-64 of life. 
Mater Medical Research Institute Limited - Confidential

794 (B) Autoimmune diabetes incidence. Site 1 (3 independent experiments, $n=23$ group). Site 2 (1 795 independent experiment, $n=14-20$ /group).

796 (C) Non-fasted blood glucose concentrations shown as linear regression $\pm 95 \%$ confidence intervals (left) 797 and residuals representing variability of blood glucose levels from the regression line (right).

798 (D-F) Pancreatic islet infiltration. (D) Islet infiltration index (0 indicates no infiltration; to 1 indicates $799>75 \%$ infiltration). (E) Degree of islet infiltration (grade 0, none; grade 1, peri-infiltration; grade 2, $<25 \%$ 800 infiltration; grade 3, 25-75\% infiltration; grade 4, $>75 \%$ infiltration). (F) Representative H\&E 801 photomicrographs $(n=7-33$ sections/group from $n=4-7$ mice/group, scale bar $=40 \mu \mathrm{m})$.

802 (G) Islet count normalized by tissue area.

803 Column graphs are shown as median (IQR) and analyzed by two-tailed Mann-Whitney U-test. Box and 804 whisker plot variances were analyzed by F-test. Degree of insulitis is shown as mean and proportions 805 analyzed by Fischer's exact test. Diabetes incidence are shown as Kaplan-Meier survival curves and were 806 analyzed by log-rank test. ${ }^{*} P<0.05, * * P<0.01, * * * P<0.001$. sRAGE, soluble receptor for advanced 807 glycation end products. 
Mater Medical Research Institute Limited - Confidential

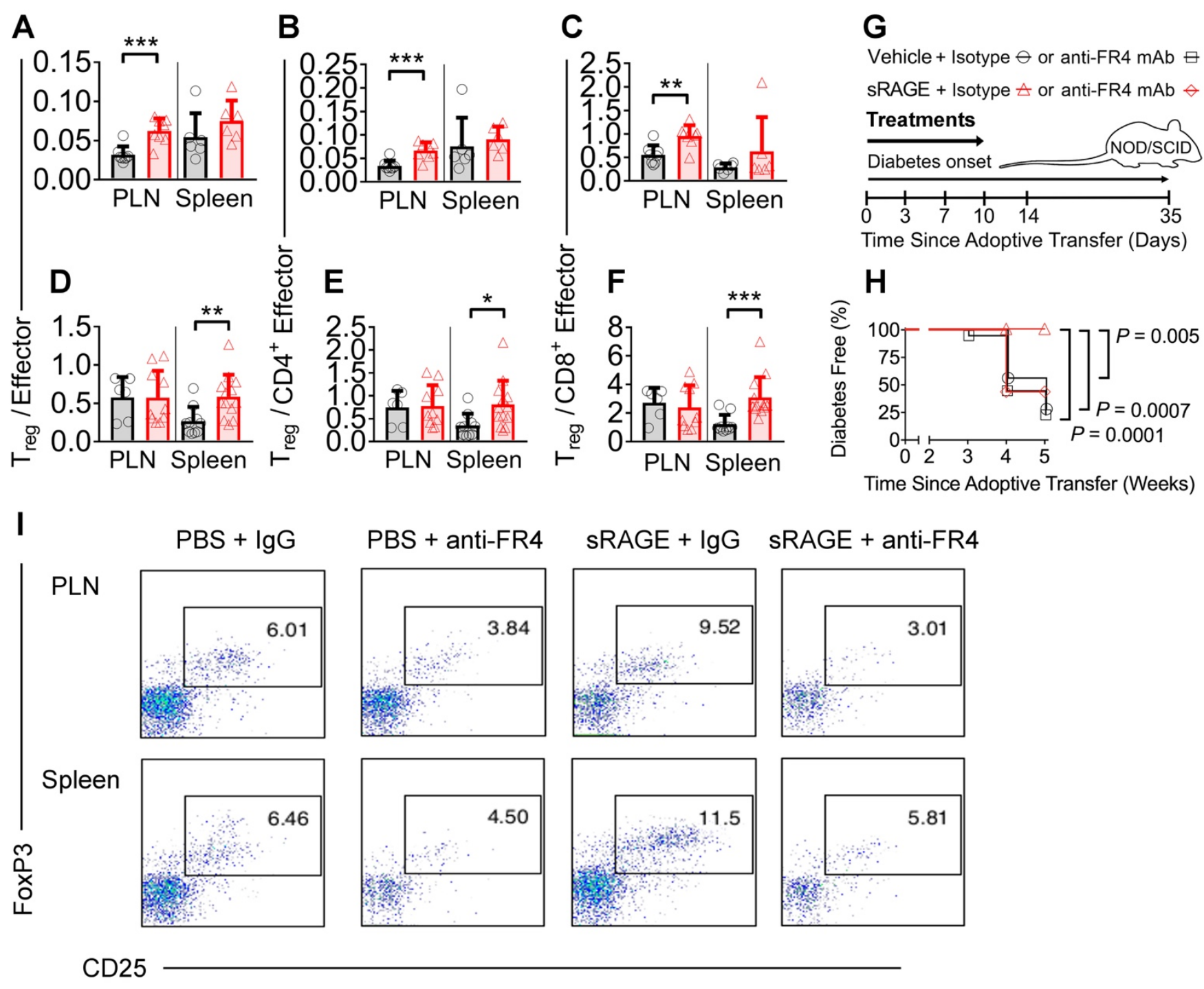

Figure 2. Regulatory $T$ cells $\left(T_{\text {regs }}\right)$ are a non-redundant mechanism of action for sRAGE treatment. mice $(n=4-13 /$ group$)$.

(G) In an adoptive transfer model of autoimmune diabetes, splenocytes from diabetic NOD/ShiLt donors were adoptively transferred into NOD/SCID recipients. Recipient mice were treated with vehicle or $25 \mu \mathrm{g}$

814 sRAGE twice daily for 14 days, and isotype control or anti-folate receptor 4 (FR4) antibodies at 3, 7, 10 815 and 14 days.

(H) Diabetes incidence; and 
bioRxiv preprint doi: https://doi.org/10.1101/2020.01.10.902627; this version posted January 11,2020 . The copyright holder for this preprint (which was not certified by peer review) is the author/funder, who has granted bioRxiv a license to display the preprint in perpetuity. It is made available under aCC-BY-ND 4.0 International license.

Mater Medical Research Institute Limited - Confidential

817 (I) Representative dot plots of $\mathrm{CD} 4^{+} \mathrm{CD} 8^{-} \mathrm{CD} 25^{+} \mathrm{FoxP} 3^{+} \mathrm{T}_{\text {reg }}$ proportions $(n=16$ mice/group).

818 Column graphs are shown as median (IQR) and analyzed by two-tailed Mann-Whitney U-test. Diabetes

819 incidence is shown as Kaplan-Meier survival curves and analyzed by log-rank test. $* P<0.05, * * P<0.01$, 820 $* * * P<0.001$. PLN, pancreatic lymph nodes. 
Mater Medical Research Institute Limited - Confidential

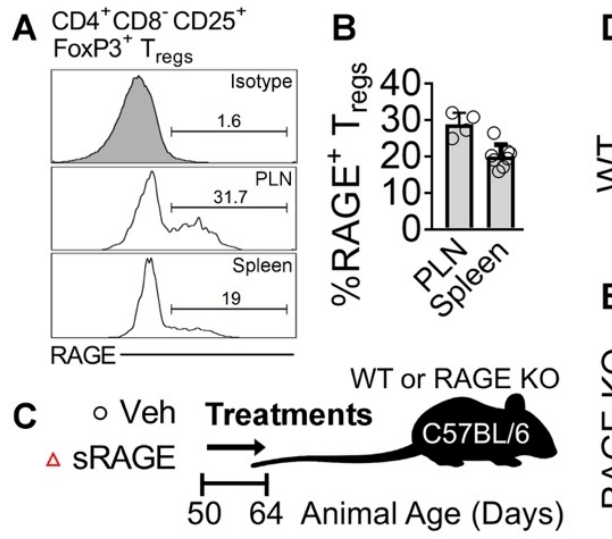

$\mathbf{F} \mathrm{CD}^{+} \mathrm{CD} 8^{-} \mathrm{CD} 25^{+}$

Fox $3^{+} T_{\text {regs }}$

밍type

$\square$ Anti-TIGIT mAb
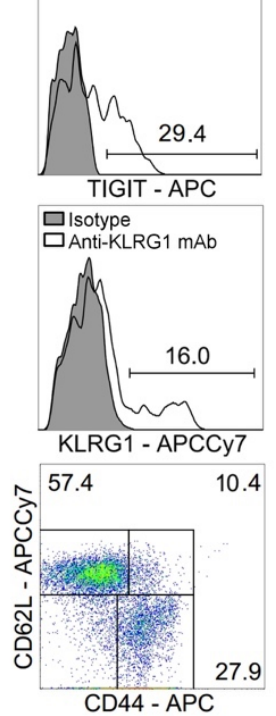

$\mathrm{CD4}^{+} \mathrm{CD}^{-} \mathrm{T}$ cells
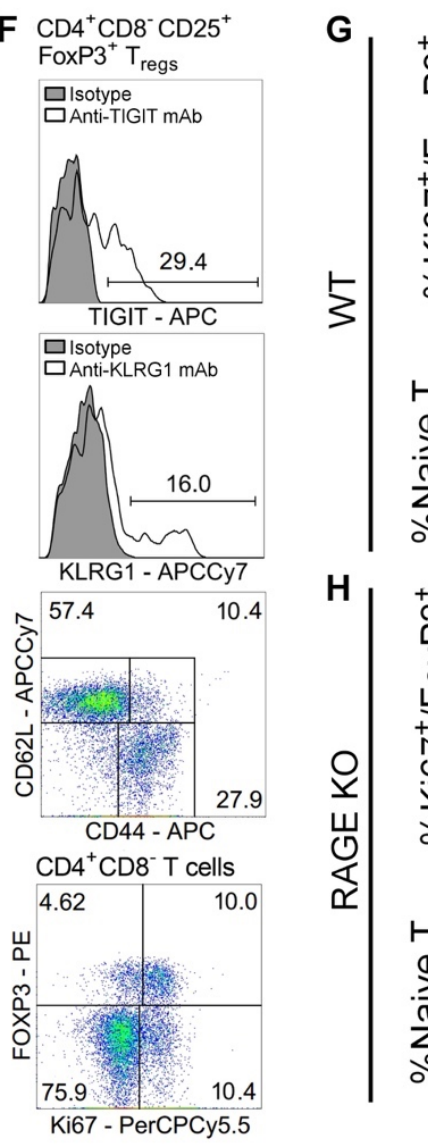
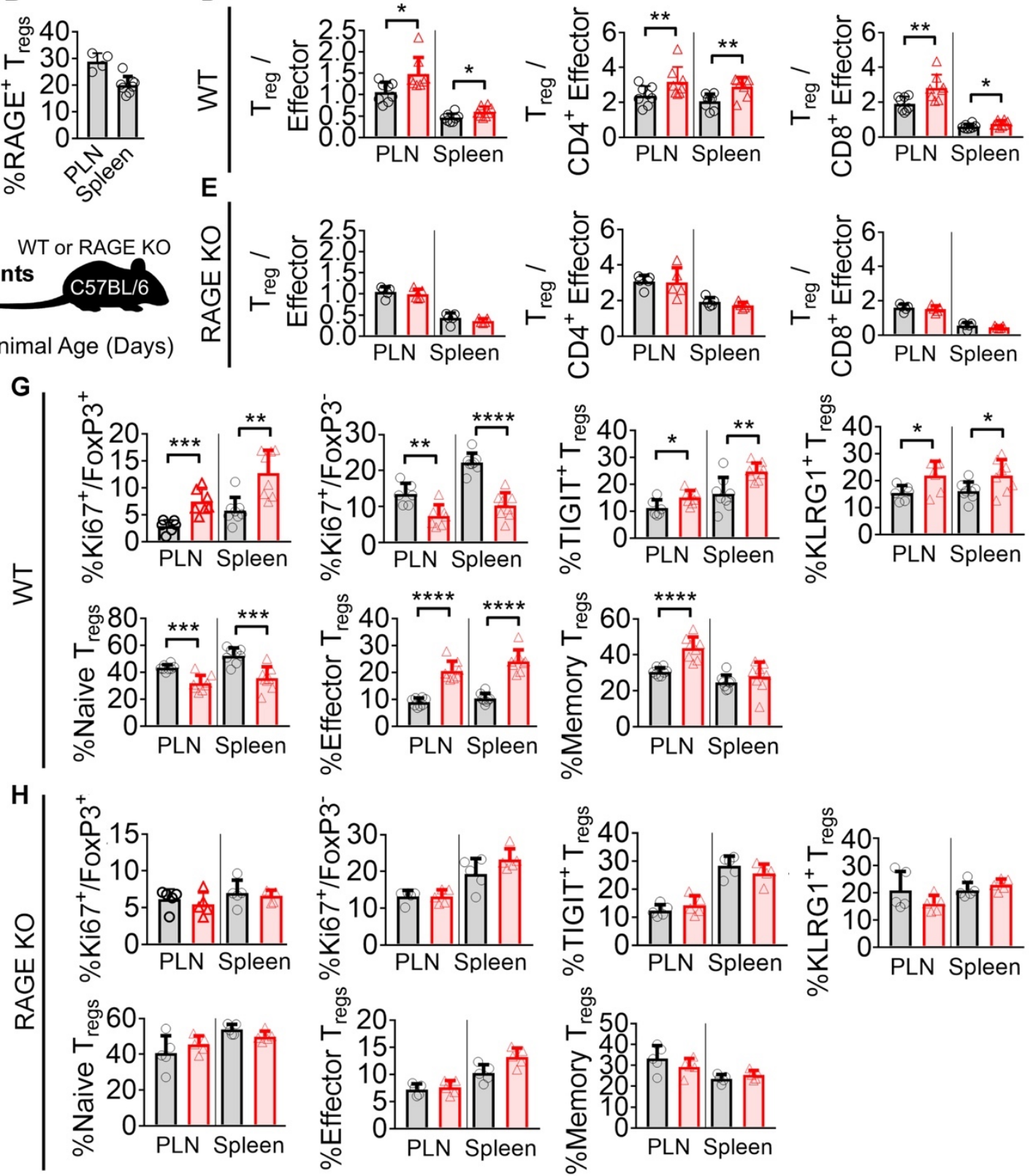

Figure 3. RAGE is required for the modulation of $\mathbf{T}_{\text {reg }} / \mathbf{T}_{\text {eff }}$ ratios by $\mathbf{s}$ AGE treatment.

(A and B) Flow cytometry quantification of RAGE expression on $\mathrm{CD}^{+} \mathrm{CD}^{-} \mathrm{CD} 25^{+} \mathrm{FoxP}^{+} \mathrm{T}_{\text {regs }}$ in a

Proportion of $\mathrm{RAGE}^{+} \mathrm{T}_{\text {regs }}(n=4-8$ mice/tissue $)$. 
Mater Medical Research Institute Limited - Confidential

826 (C) Wild-type and RAGE KO C57BL/6 mice were treated with vehicle (black bars/circles) or $25 \mu \mathrm{g}$ 827 sRAGE twice daily (red bars/triangles) on day 50-64 of life.

828 (D and E) $\mathrm{T}_{\text {reg }} / \mathrm{T}_{\text {eff }}$ ratios on day 64 in (D) wild-type and (E) RAGE KO mice ( $n=8$ mice/group).

829 (F-H) TIGIT, KLRG1, CD62L, CD44 and Ki67 expression. (F) Representative histograms and gating 830 strategies. (G) Wild-type mice. (H) RAGE KO mice.

831 Column graphs are shown as mean $\pm \mathrm{SD}$ and analyzed by two-tailed Student's t-test. $* P<0.05, * * P<0.01$, 832 $* * * P<0.001, * * * * P<0.0001$ 
Mater Medical Research Institute Limited - Confidential

A

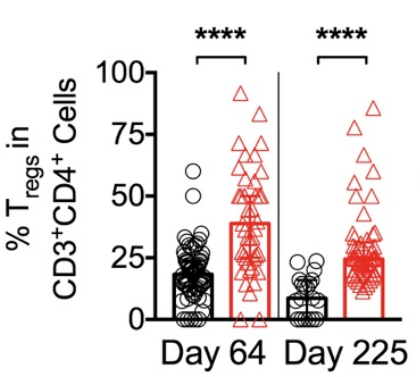

B

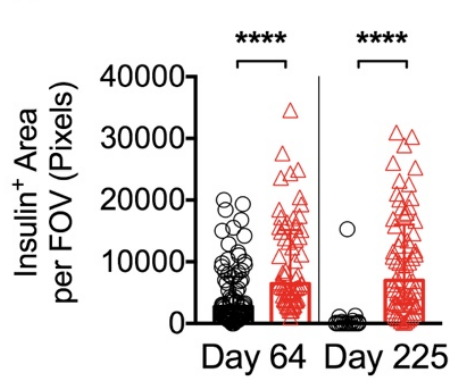

C
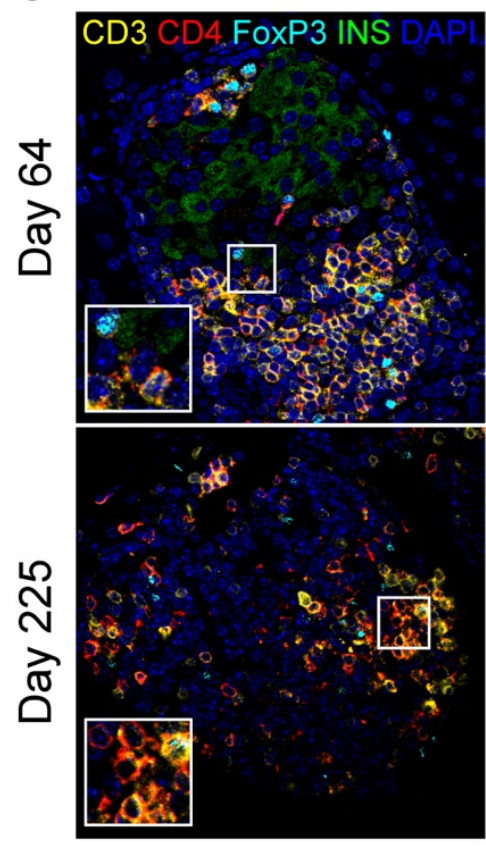
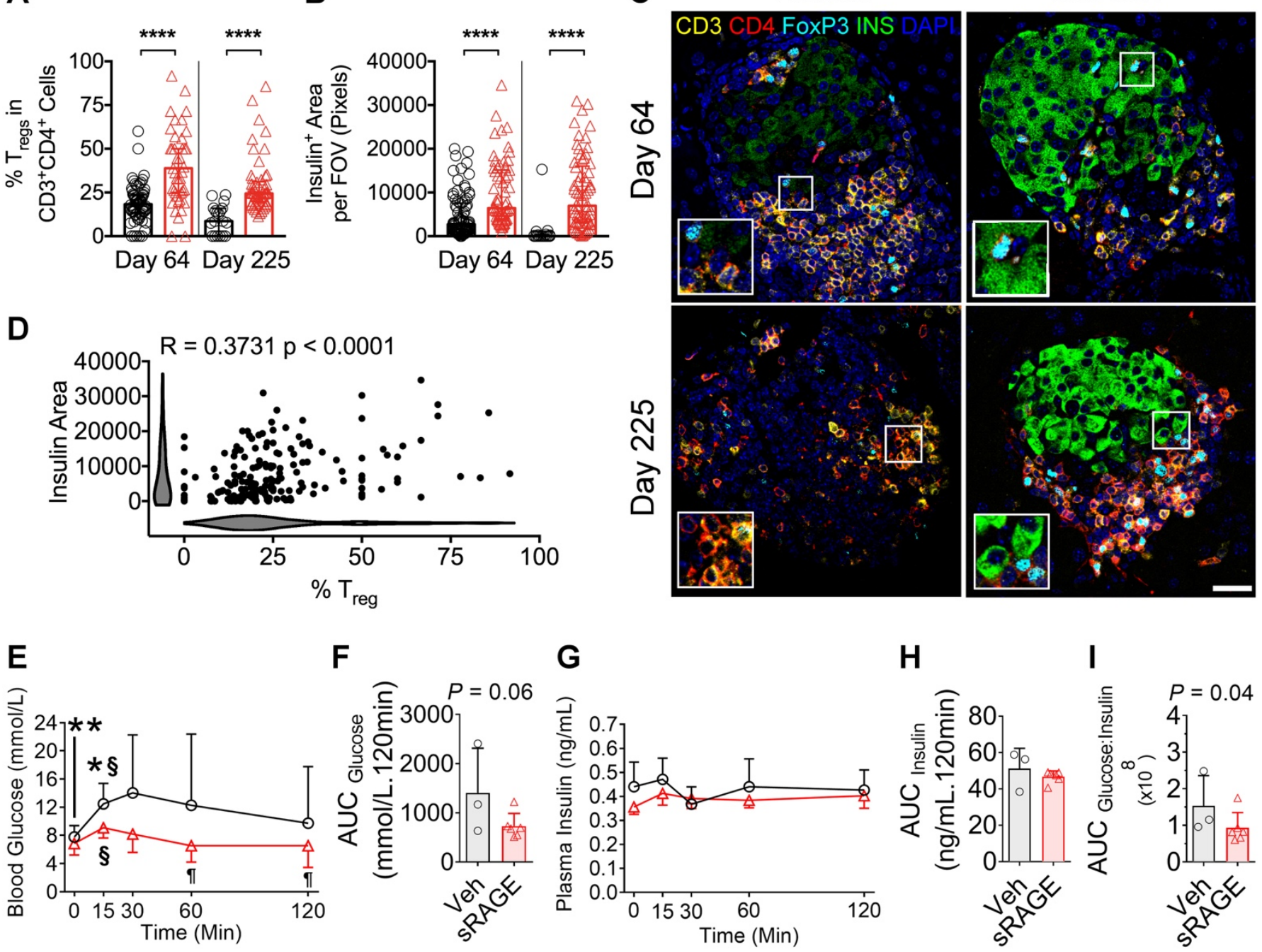

Figure 4. Improvements in islet infiltrating $\mathbf{T}_{\text {regs, }}$ insulin expression and oral glucose tolerance following sRAGE treatment in NOD/ShiLt mice.

836 (A-D) Multiplexed immunofluorescence staining and quantification of CD3, CD4, FoxP3, insulin and DAPI ( $n=10-20$ sections/mouse from $n=6$ mice/group). Inset images are 2x magnified. (A) Proportion of islet infiltrating $\mathrm{CD}^{+} \mathrm{CD}^{+} \mathrm{FoxP}^{+} \mathrm{T}_{\text {regs. }}$ (B) Insulin area per field of view (FOV). (C) Representative 839 photomicrographs. Bar, $40 \mu \mathrm{m}$. (D) Correlation analyses of $\mathrm{CD}^{+} \mathrm{CD}^{+} \mathrm{FoxP} 3^{+} \mathrm{T}_{\text {reg }}$ proportions and insulin area (shaded bars are Kernel plots showing variable distribution). 
Mater Medical Research Institute Limited - Confidential

841 (E-I) Oral glucose tolerance tests (OGTTs) on day 225 ( $n=3-6 /$ group). (E) Blood glucose concentrations;

842 (F) Area under the curve for blood glucose (AUC $\mathrm{Alucose}_{\text {) }}(\mathrm{G})$ Plasma insulin concentrations; $(\mathrm{H}) \mathrm{AUC}$ insulin;

843 (I) $\mathrm{AUC}_{\text {glucose:insulin ratio. }}$

844 Data shown as mean \pm SD and analyzed by two-tailed unpaired or paired Student t-tests. Correlation 845 analyses were performed by Spearman's test. $* P<0.05$ between groups, $* * P<0.01$ between groups, $846 * * * * P<0.0001$ between groups. $\S \mathrm{P}<0.05$ vs. 0 min within the same group, $\uparrow \mathrm{P}<0.05$ vs. 15 or 30 min 847 time points within the same group. 
Mater Medical Research Institute Limited - Confidential
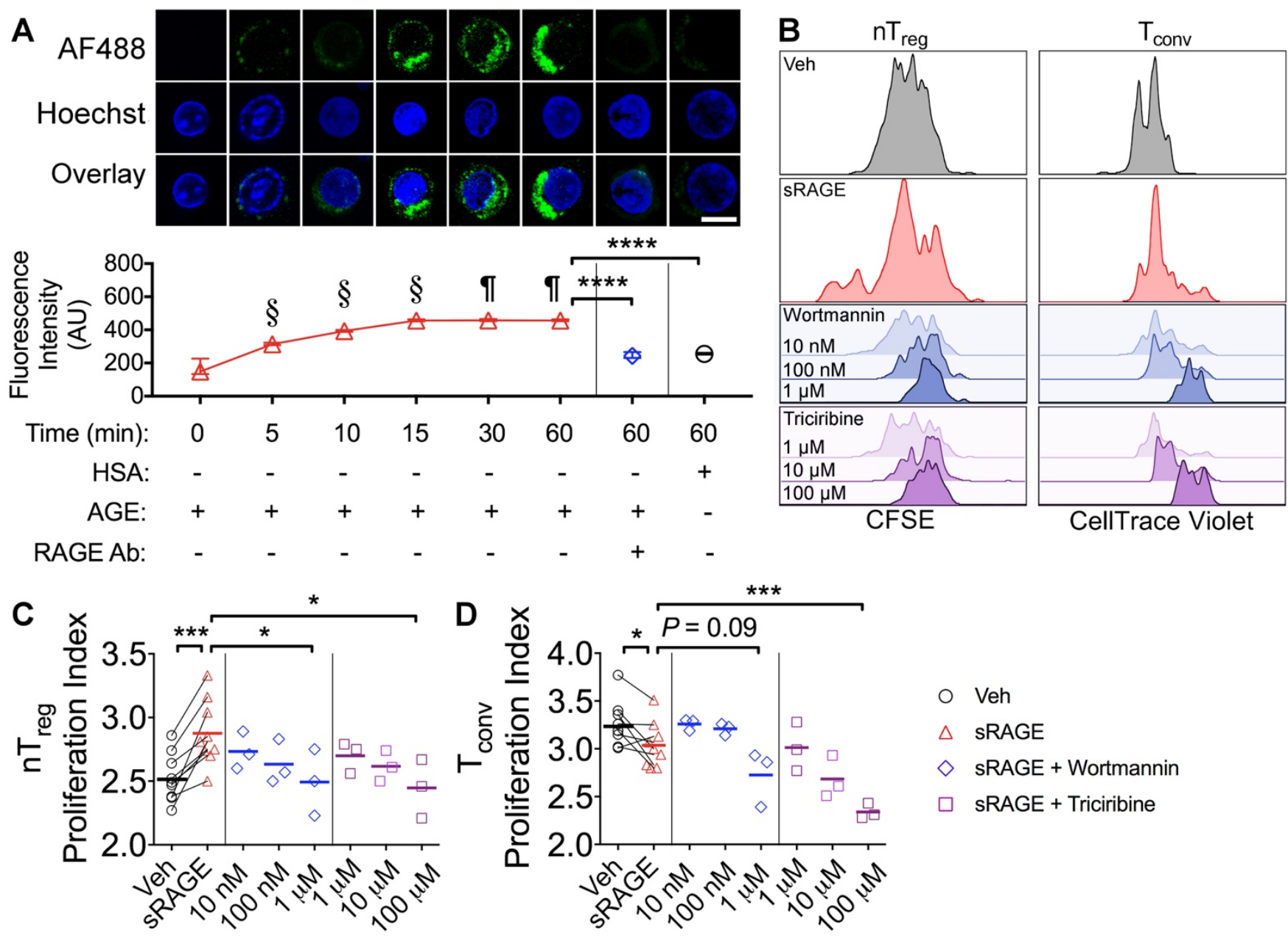

O Veh

$\triangle$ SRAGE

E

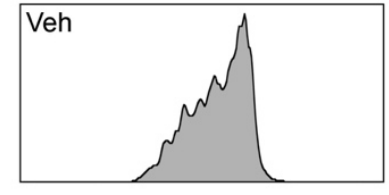

CFSE
$\mathbf{F}$
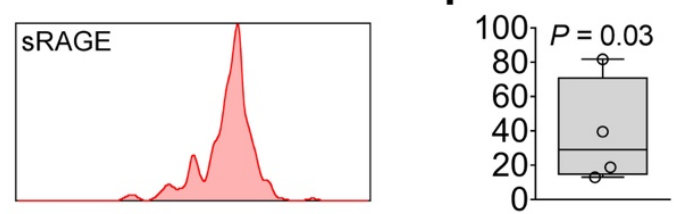

$\%$ Change in $\mathrm{nT}_{\text {reg }} \mathrm{MFI}$

(sRAGE vs. vehicle)

Figure 5. Human natural $T_{\text {regs }}\left(n T_{\text {regs }}\right)$ bind AGEs in a RAGE-dependent manner and proliferate more in co-culture when treated with SRAGE.

(A) Human $\mathrm{CD}^{+} \mathrm{CD}^{+} \mathrm{CD} 25^{+} \mathrm{CD} 127^{\mathrm{lo} /-} \mathrm{nT}$ regs were incubated with AGE-modified HSA (AGE-HSA or AGE) or unmodified HSA (HSA), both labelled with AlexaFluor488 (AF488). Anti-RAGE antibody was added to the culture as indicated. Bar, $10 \mu \mathrm{m} . n=3$ donors/group. 
Mater Medical Research Institute Limited - Confidential

854 (B-D) CFSE labeled $\mathrm{CD}^{+} \mathrm{CD}^{+} \mathrm{CD} 25^{+} \mathrm{CD} 127^{\mathrm{lo} /-} \mathrm{nT}$ regs and CellTrace Violet labeled $\mathrm{CD} 3^{+} \mathrm{CD} 4^{+} \mathrm{CD} 25^{-}$

$855 \mathrm{~T}_{\text {convs }}$ were stimulated in 3 day co-culture at a 1:1 ratio containing anti-CD3/CD28 MACSiBeads (1:10,

856 bead:cell ratio). (B) Representative histograms. (C-D) Proliferation indices of $\mathrm{nT}_{\text {regs }}$ and $\mathrm{T}_{\text {convs }}$ when

857 administered vehicle or $50 \mu \mathrm{g}$ sRAGE daily ( $n=9$ /group), as well as sRAGE in addition to the PI3K-Akt858 mTOR pathway inhibitors wortmannin or triciribine ( $n=3$ /group).

859 (E and F) CFSE labeled $\mathrm{CD}^{+} \mathrm{CD}^{+} \mathrm{CD} 25^{+} \mathrm{CD} 127^{\mathrm{lo}-}-\mathrm{nT}$ regs were stimulated in 3 day monoculture 860 containing anti-CD3/CD28 MACSiBeads (1:20, bead:cell) and $200 \mathrm{IU} / \mathrm{mL}$ IL-2. (E) Representative 861 histograms. (F) Percent change in CFSE mean fluorescence intensity (MFI; $n=4$ /group).

862 Data shown as mean $\pm \mathrm{SD}$; paired two-tailed Student's t-tests. $\S \mathrm{P}<0.05$ vs. all previous time points. ๆ $\mathrm{P}<$ 863 0.05 vs. $0,5,10$ and 15 min. $* P<0.05, * * * P<0.001 . * * * * P<0.0001$. 
bioRxiv preprint doi: https://doi.org/10.1101/2020.01.10.902627; this version posted January 11,2020 . The copyright holder for this preprint (which was not certified by peer review) is the author/funder, who has granted bioRxiv a license to display the preprint in perpetuity. It is made available under aCC-BY-ND 4.0 International license.

Mater Medical Research Institute Limited - Confidential

A

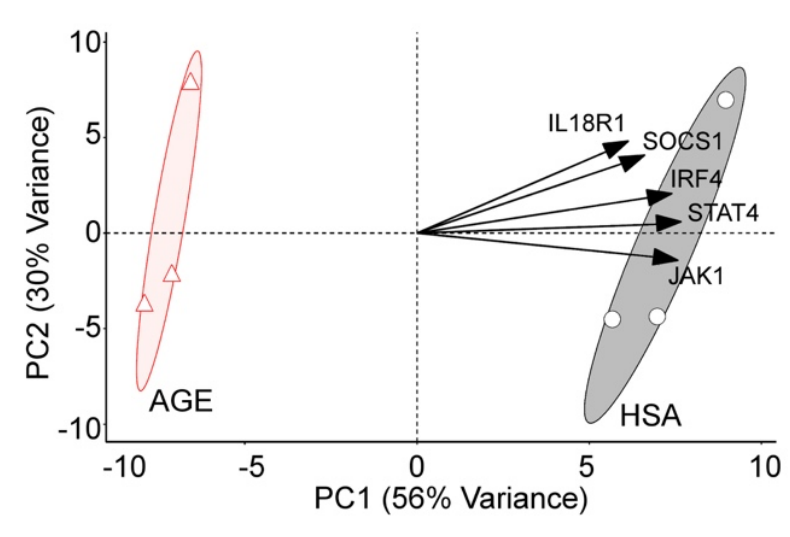

C

Gene Ontology Interleukin signalling pathway
PDGF signalling pathway Inflammation mediated by chemokine and cytokine EGF receptor signalling pathway
E

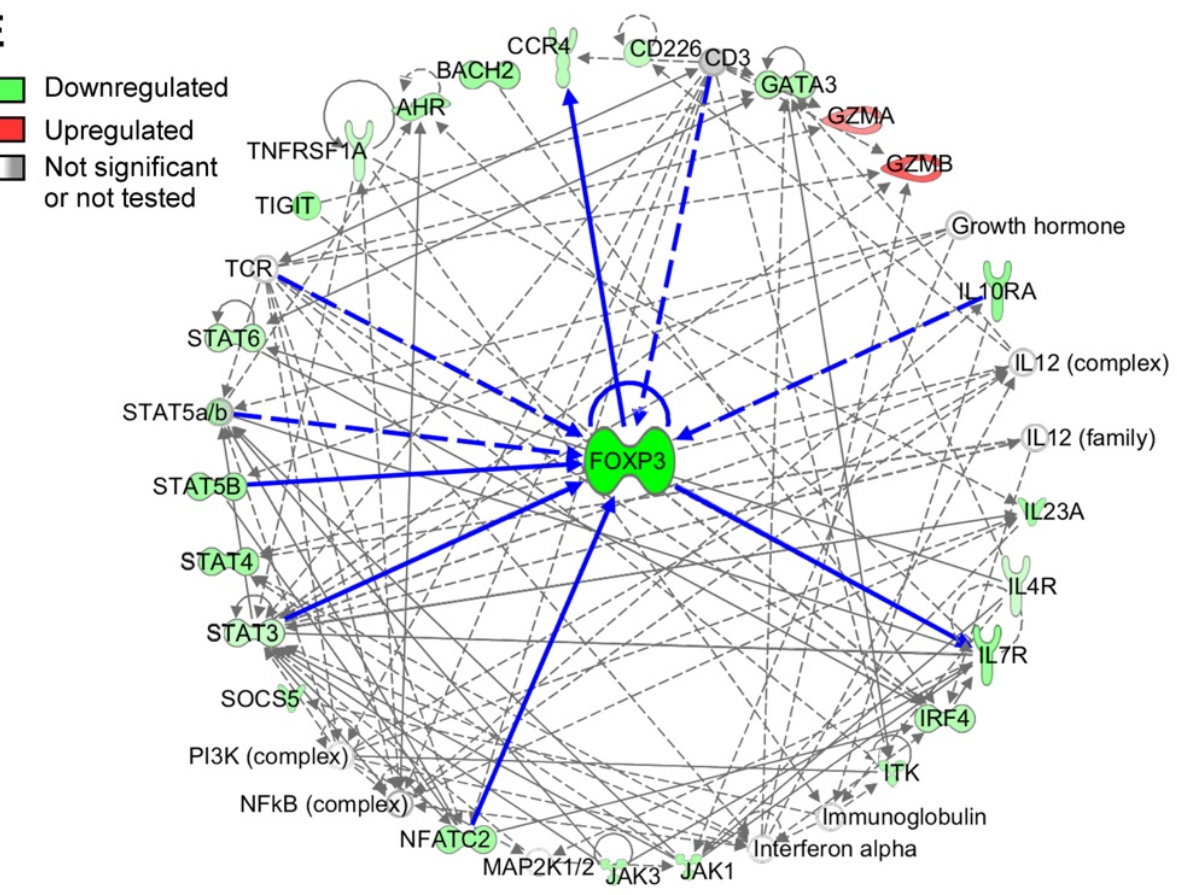
manipulates signaling cascades upstream and downstream of FOXP3.
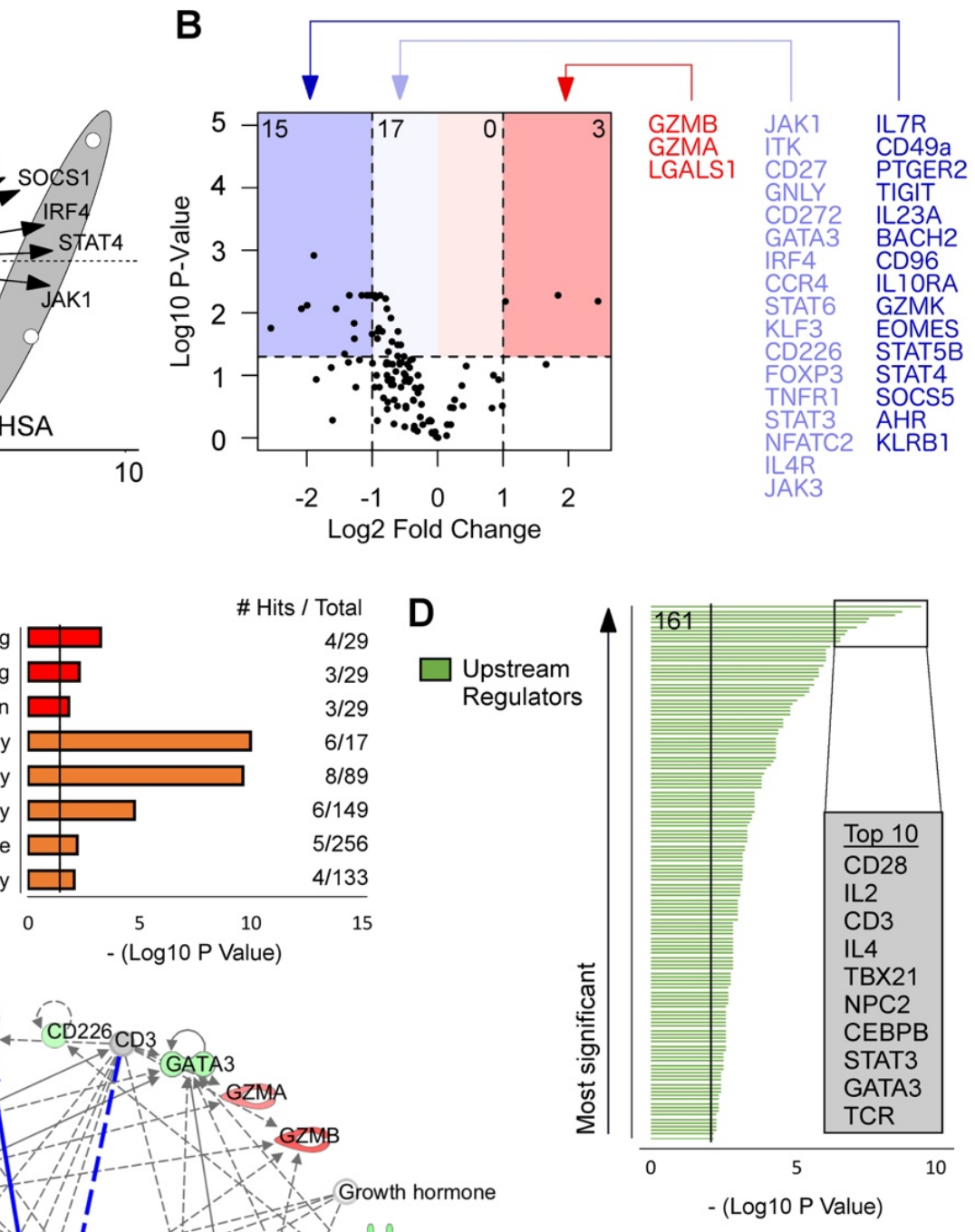

Figure 6. AGE treatment of human $n T_{\text {regs }}$ downregulates key genes for suppressive function and 
Mater Medical Research Institute Limited - Confidential

867 (A) Principal component analysis (PCA) with the top five variable loadings shown as arrows.

868 (B) Volcano plot visualization for changes in gene expression (number of differentially expressed genes 869 shown in top corners).

870 (C) Pathway enrichment analysis using the Reactome and Gene Ontology databases.

871 (D) Upstream regulator predictions using Ingenuity Pathway Analysis (161 significant regulators were 872 identified).

873 (E) Network analysis using FOXP3 as the focus node. Neighboring molecules are connected to FOXP3 874 with bolded blue lines. All other molecules are 2-3 nodes adjacent to FOXP3. Direct relationships are 875 shown as solid lines, indirect relationships are shown as dashed lines.

$876 n=3$ /group, $P$ values were corrected by false discovery rate or Bonferroni adjustment. 
bioRxiv preprint doi: https://doi.org/10.1101/2020.01.10.902627; this version posted January 11,2020 . The copyright holder for this preprint (which was not certified by peer review) is the author/funder, who has granted bioRxiv a license to display the preprint in perpetuity. It is made available under aCC-BY-ND 4.0 International license.

Mater Medical Research Institute Limited - Confidential

\section{Tables}

878 Table 1. Plasma concentrations of RAGE ligands in NOD/ShiLt mice.

879 Data shown as median (IQR); two-tailed Mann-Whitney U-test; $n=12-15 /$ group. ${ }^{*} P<0.05$ vs.

880 vehicle at same time point. Lys, lysine.

\begin{tabular}{|c|c|c|c|c|}
\hline \multirow{2}{*}{$\begin{array}{l}\text { Age } \\
\text { Treatment }\end{array}$} & \multicolumn{2}{|c|}{ Day 64} & \multicolumn{2}{|c|}{ Day 225} \\
\hline & Vehicle & SRAGE & Vehicle & SRAGE \\
\hline CML (nmol/mmol Lys) & $32.2(3.5)$ & $31.1(3.7)$ & $76.5(10.6)$ & $71.1(12.4)^{*}$ \\
\hline CEL (nmol/mmol Lys) & $13.5(4.0)$ & $16.2(8.0)$ & $15.4(3.8)$ & $12.3(4.2)^{*}$ \\
\hline MG-H1 (nmol/mmol Lys) & $229.3(45.1)$ & $260.1(56.4)$ & $267.7(39.5)$ & $247.0(54.6)^{*}$ \\
\hline MGO (nmol/L) & $499.5(78.8)$ & $436.4(142.9)$ & $643.7(280.2)$ & $556.1(246.4)$ \\
\hline $\mathrm{GO}(\mathrm{nmol} / \mathrm{L})$ & $848.4(301.8)$ & $958.3(316.0)$ & $1083.0(505.2)$ & $1004.0(518.5)$ \\
\hline 3-DG (nmol/L) & $987.3(254.7)$ & $1163.0(401.0)$ & $2547.0(476.0)$ & $2227.0(483.0)$ \\
\hline $\mathrm{S} 100 \mathrm{~A} 8(\mathrm{ng} / \mathrm{mL})$ & $0.5(0.1)$ & $7.1(23.0)$ & $5.3(13.1)$ & $5.0(26.0)$ \\
\hline S100A9 (ng/mL) & $166.8(131.8)$ & $301.3(303.0)$ & $74.9(144.3)$ & $100.5(81.8)$ \\
\hline $\mathrm{S} 100 \mathrm{~B}(\mathrm{ng} / \mathrm{mL})$ & $1081.0(812.9)$ & $882.5(512.7)$ & $1052.0(528.8)$ & $1077.0(545.6)$ \\
\hline HMGB1 (ng/mL) & $11.9(7.5)$ & $15.8(8.2)$ & $7.1(3.7)$ & $5.7(5.0)$ \\
\hline
\end{tabular}

881 
Mater Medical Research Institute Limited - Confidential

\section{Supplemental Figures Titles and Legends}

883

884

885

886

887

888

889

890

891

892

893

894

895

896

897

898

899

900

901

902

Figure S1. Flow cytometry gating strategy for mouse $T$ cells.

(A) Debris were excluded and single cells gated.

(B) Conventional $\mathrm{T}$ cells $\left(\mathrm{T}_{\text {convs }}\right)$ : FoxP3 ${ }^{+} \mathrm{T}_{\text {regs }}$ were excluded, then $\mathrm{CD} 4^{+} \mathrm{CD} 8^{-}$and $\mathrm{CD} 8^{+} \mathrm{CD} 4^{-} \mathrm{T}$ cells were gated. Naïve, effector $\left(\mathrm{T}_{\mathrm{eff}}\right)$ and memory cells were defined as $\mathrm{CD}^{2} \mathrm{~L}^{+} \mathrm{CD}^{4} 4^{-}$, $\mathrm{CD}^{-} \mathrm{L}^{-} \mathrm{CD} 44^{+}$and $\mathrm{CD} 62 \mathrm{~L}^{+} \mathrm{CD} 44^{+}$, respectively.

(C) $\mathrm{T}_{\text {regs: }} \mathrm{CD}^{+} \mathrm{CD}^{-} \mathrm{T}$ cells were gated, then $\mathrm{CD}^{+} \mathrm{CD}^{-} \mathrm{CD} 25^{+} \mathrm{Foxp} 3^{+} \mathrm{T}_{\text {regs }}$ were gated.

Figure S2. sRAGE increases the numbers of $\mathrm{CD4}^{+} \mathrm{CD8}^{-} \mathrm{CD25}^{+} \mathrm{Foxp3}^{+} \mathrm{T}_{\text {regs }}$ and $\mathrm{T}_{\text {convs }}$ in the pancreatic lymph nodes (PLN) and spleen on day 64.

(A) $\mathrm{CD} 4^{+} \mathrm{CD} 8^{-} \mathrm{CD} 25^{+} \mathrm{Foxp}^{+} \mathrm{T}_{\text {regs. }}$.

(B) $\mathrm{CD}^{+} \mathrm{FoxP}^{-} \mathrm{T}_{\text {convs }}$; and

(C) $\mathrm{CD}^{+} \mathrm{FoxP}^{-} \mathrm{T}_{\text {convs, }}$ accompanied with their $\mathrm{CD} \mathrm{LL}^{+} \mathrm{CD}^{-} 4^{-}$naïve, $\mathrm{CD}^{-} \mathrm{L}^{-} \mathrm{CD} 44^{+}$effector ( $\mathrm{T}_{\text {eff }}$ ) and $\mathrm{CD}_{2} \mathrm{~L}^{+} \mathrm{CD} 44^{+}$memory subsets.

Two-tailed Mann-Whitney U-test. $n=4$-13/group. ${ }^{*} P<0.05$; $* * P<0.01$.

Figure S3. sRAGE decreases the numbers of $\mathrm{CD4}^{+} \mathrm{CD8}^{-} \mathrm{CD}^{+} 5^{+} \mathrm{Foxp3}^{+} \mathrm{T}_{\text {regs }}$ and $\mathrm{T}_{\text {convs }}$ in the PLN and spleen on day 225.

(A) $\mathrm{CD}^{+} \mathrm{CD} 8{ }^{-} \mathrm{CD} 25^{+} \mathrm{Foxp}^{+} \mathrm{T}_{\text {regs. }}$.

(B) $\mathrm{CD}^{+} \mathrm{FoxP}^{-} \mathrm{T}_{\text {convs }}$; and

(C) $\mathrm{CD}^{+} \mathrm{FoxP}^{-} \mathrm{T}_{\text {convs, }}$, accompanied with their $\mathrm{CD} 2 \mathrm{~L}^{+} \mathrm{CD}^{-} 4^{-}$naïve, $\mathrm{CD}^{-} \mathrm{L}^{-} \mathrm{CD} 44^{+}$effector ( $\left.\mathrm{T}_{\mathrm{eff}}\right)$ and $\mathrm{CD} 2 \mathrm{~L}^{+} \mathrm{CD} 44^{+}$memory subsets.

Two-tailed Mann-Whitney U-test. $n=4-13$ /group. ${ }^{*} P<0.05 ; * * * P<0.001$. 
Mater Medical Research Institute Limited - Confidential

903

904

905

906

907

908

909

910

911

912

913

914

915

916

917

918

919

920

921

922

923

924

Figure S4. sRAGE increases the numbers of dendritic cells and macrophages on day 64.

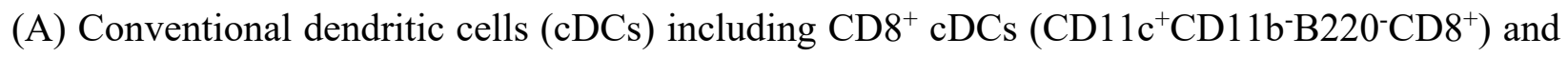

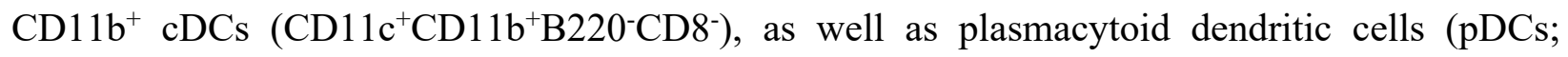
CD11 $\left.\mathrm{c}^{+} \mathrm{CD} 11 \mathrm{~b}-\mathrm{B} 220^{+}\right)$.

(B) Macrophages $\left(\mathrm{F} 4 / 80^{+} \mathrm{CD} 11 \mathrm{c}^{-} \mathrm{CD} 11 \mathrm{~b}^{+} \mathrm{B} 220^{\mathrm{int} / h i}\right)$.

Figure S5. Prediabetes oral glucose tolerance tests (OGTTs).

(A-E) OGTTs on day 64 ( $n=8 /$ group).

(F-J) OGTTs on day 80 ( $n=15 /$ group $)$.

(A, F) Blood glucose concentrations; $(\mathrm{B}, \mathrm{G})$ Area under the curve for blood glucose (AUC $\mathrm{glucose}_{\text {) }}$;

$(\mathrm{C}, \mathrm{H})$ Plasma insulin concentrations; (D, I) $\mathrm{AUC}_{\text {insulin; }}(\mathrm{E}, \mathrm{J}) \mathrm{AUC}_{\text {glucose:insulin }}$ ratio.

Data shown as mean $\pm \mathrm{SD}$ and analyzed by two-tailed unpaired Student t-tests. ${ }^{*} P<0.05$ between groups.

Figure S6. Gating strategies for human T cell proliferation experiments.

(A and $\mathrm{B}) \mathrm{CD}^{+} \mathrm{CD}^{+} \mathrm{CD} 25^{+} \mathrm{CD} 127^{\mathrm{lo} /-}$ natural $\mathrm{T}_{\text {regs }}\left(\mathrm{nT}_{\text {regs }}\right)$ and $\mathrm{CD}^{+} \mathrm{CD}^{+} \mathrm{CD}^{+} 5^{-} \mathrm{T}_{\text {convs }}$ were positively isolated by FACS.

(C and D) $\mathrm{CD}^{+} \mathrm{CD}^{+} \mathrm{CD} 25^{+} \mathrm{CD} 127^{\mathrm{lo} /-} \mathrm{nT}$ regs were assessed for FoxP3 expression.

(E-G) Gating strategy for analyzing $\mathrm{nT}_{\text {reg }}$ and $\mathrm{T}_{\text {conv }}$ proliferation when co-cultured. (E) Debris, multiplets and dead cells were excluded, (F) $\mathrm{CD} 3{ }^{+} \mathrm{CD} 4^{+}$cells were gated. $\mathrm{CD} 3{ }^{+} \mathrm{CD} 4^{+}$cells were then analyzed for $\mathrm{nT}_{\text {reg }}$ and $\mathrm{T}_{\text {conv }}$ proliferation by CFSE and CellTrace Violet dilution, respectively. (G) $n T_{\text {regs }}$ and $\mathrm{T}_{\text {convs }}$ were both $\mathrm{CD} 25^{+} \mathrm{CD} 127^{\mathrm{lo} /}$ post-stimulation, so $\mathrm{CD} 25$ and CD127 expression was not used to delineate $\mathrm{T}_{\text {regs }}$ and $\mathrm{T}_{\text {convs }}$ prior to CFSE and CellTrace Violet dye dilution analysis. 
Mater Medical Research Institute Limited - Confidential

925

926

927

(H-J) Gating strategy for analyzing $\mathrm{nT}_{\text {reg }}$ proliferation when cultured alone. (H) Debris, multiplets and dead cells were excluded, (I) $\mathrm{CD}^{+} \mathrm{CD}^{+}$cells were gated, (J) $\mathrm{CD} 127^{\mathrm{lo} /-}$ cells were gated as $\mathrm{nT}_{\text {regs. }} \mathrm{nT}_{\text {regs }}$ were then analyzed for proliferation by CFSE dilution.

Figure S7. Gating strategies for human induced $\mathbf{T}_{\text {reg }}\left(\mathbf{i T}_{\text {reg }}\right)$ differentiation experiment.

(A and B) Purity check for naive $\mathrm{CD}^{+} \mathrm{T}$ cells $\left(\mathrm{CD} 3^{+} \mathrm{CD} 4^{+} \mathrm{CD} 45 \mathrm{RA}^{+} \mathrm{CD} 45 \mathrm{RO}^{-}\right)$(A) before negative isolation (peripheral blood mononuclear cells, PBMCs) and (B) after negative isolation. (C-E) Gating strategy for analyzing $i \mathrm{~T}_{\text {reg }}$ differentiation. (C) Debris, multiplets and dead cells were excluded, (D) $\mathrm{CD}^{+} \mathrm{CD}^{+}$cells were gated, (E) $\mathrm{CD} 25^{+} \mathrm{CD} 127^{1 /-}$ cells were gated as $\mathrm{iT}_{\text {regs. }}$.

Figure S8. Human iT $_{\text {reg }}$ differentiation in AGE-containing culture media is modestly decreased by sRAGE treatment.

Human naive $\mathrm{CD}^{+} \mathrm{CD}^{+} \mathrm{CD} 45 \mathrm{RA}^{+} \mathrm{CD} 45 \mathrm{RO}^{-} \mathrm{T}$ cells were incubated in 3 day co-culture containing $5 \mathrm{ng} / \mathrm{mL}$ IL-2, $2 \mathrm{ng} / \mathrm{mL}$ TGF- $\beta$ and $1 \mu \mathrm{g} / \mathrm{mL}$ plate-bound anti-CD3 antibody.

(A) Representative dot plots of $\mathrm{CD}^{+} \mathrm{CD}^{+} \mathrm{CD} 25^{+} \mathrm{CD} 127^{\mathrm{lo} /-} \mathrm{iT}$ regs in AGE-supplemented media with co-administration of vehicle or sRAGE $(50 \mu \mathrm{g} / \mathrm{day})$.

(B) Quantification of change in $\mathrm{iT}_{\text {reg }}$ differentiation by sRAGE treatment. Data shown as mean \pm SD; paired t-tests; $n=4$ /group.

Table S1. Human $\mathrm{nT}_{\text {reg }}$ NanoString predicted upstream regulators.

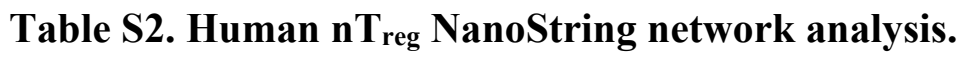

Table S3. Human $n T_{\text {reg }}$ NanoString volcano plot values. 